Fizik, Kimya ve Biyoloji Öğretmenlerinin Eğitim Felsefesi Tercihlerinin ve Bilimsel Epistemolojik İnançlarının Çeşitli Değişkenler Açısından İncelenmesi

Tuğba Taşkın

Matematik ve Fen Bilimleri Eğitimi Bölümü, Gazi Eğitim Fakültesi, Gazi Üniversitesi, Ankara, Türkiye

Sorumlu Yazar: Tuğba Taşkın, tugbataskin2@gmail.com

Makale Türü: Araştırma Makalesi

Kaynak Gösterimi: Taşkın, T. (2020). Fizik, kimya ve biyoloji öğretmenlerinin eğitim felsefesi tercihlerinin ve bilimsel epistemolojik inançlarının çeşitli değişkenler açısından incelenmesi. Eğitimde Kuram ve Uygulama, 16(1), 1-19. doi: $10.17244 /$ eku. 648820

Examining Science Philosophy Preferences and Scientific Epistemological Beliefs of Physics, Chemistry and Biology

Teachers Regarding to Several Variables

Tuğba Taşkın

Department of Mathematics and Science Education, Gazi Faculty of Education, Gazi University, Ankara, Turkey

Corresponding Author: Tuğba Taşkın, tugbataskin2@gmail.com

Article Type: Research Article

To Cite This Article: Taşkın, T. (2020). Fizik, kimya ve biyoloji öğretmenlerinin eğitim felsefesi tercihlerinin ve bilimsel epistemolojik inançlarının çeşitli değişkenler açısından incelenmesi. Eğitimde Kuram ve Uygulama, 16(1), 1-19. doi: $10.17244 /$ eku. 648820 


\title{
Fizik, Kimya ve Biyoloji Öğretmenlerinin Eğitim Felsefesi Tercihlerinin ve Bilimsel Epistemolojik İnançlarının Çeşitli Değişkenler Açısından İncelenmesi
}

\author{
Tuğba Taşkın \\ Matematik ve Fen Bilimleri Eğitimi Bölümü, Gazi Ĕ̆itim Fakültesi, Gazi Üniversitesi, Ankara, Türkiye \\ ORCID: https://orcid.org/0000-0002-8738-0012
}

\begin{tabular}{|c|c|}
\hline$\ddot{\mathbf{O} z}$ & Makale Bilgisi \\
\hline $\begin{array}{l}\text { Bu araştırmanın amacı, fizik, kimya ve biyoloji öğretmenlerinin tercih ettikleri eğitim } \\
\text { felsefelerini, bilimsel epistemolojik inançlarını ve bunlar arasındaki ilişkiyi çeşitli } \\
\text { değişkenler açısından incelemektir. Araştırmanın çalışma grubunu, devlet okullarında } \\
\text { görev yapmakta olan } 50 \text { fizik öğretmeni, } 51 \text { kimya öğretmeni, } 50 \text { biyoloji öğretmeni } \\
\text { olmak üzere, } 151 \text { fen bilimleri öğretmeni oluşturmaktadır. İlişkisel tarama modeline göre } \\
\text { gerçekleştirilen çalışmada verilerin toplanmasında "Felsefi Tercih Değerlendirme Formu" } \\
\text { ve "Bilimsel "Epistemolojik İnanç Ölçeği" kullanılmıştır. Elde edilen veriler cinsiyet ve } \\
\text { branş değişkenleri açısından incelenmiştir. Verilerin analizi için betimsel istatistikler, çok } \\
\text { değişkenli varyans analizi (MANOVA) ve korelasyon analizinden yararlanılmıştır. } \\
\text { Yapılan analizler sonucunda elde edilen bulgulara göre öğretmenler arasında en fazla } \\
\text { tercih edilen eğitim felsefesinin "deneyselcilik" olduğu görülmüştür. Fizik, kimya ve } \\
\text { biyoloji öğretmenlerinin eğitim felsefesi tercihleri üzerinde cinsiyet değişkeninin etkisi } \\
\text { incelendiğinde, deneyselcilik boyutunda erkek öğretmenler lehine anlamlı farklılık } \\
\text { bulunmuştur. Branş değişkeni açısından yapılan analizlerde, öğretmenlerin branşlarının } \\
\text { eğitim felsefesi tercihleri üzerinde etkisi olmadığ görülmüştür. Bilimsel Epistemolojik } \\
\text { İnanç Ölçeğinden elde edilen bulgular dikkate alındığında ise, öğretmenlerin tüm } \\
\text { boyutlarda "gelişmiş" bilimsel epistemolojik inançlara sahip oldukları belirlenmiştir. } \\
\text { Öğretmenlerin bilimsel epistemolojik inançları üzerinde cinsiyet değişkeninin etkisinin } \\
\text { olmadığı görülmüştür. Branş değişkeni bakımından, öğretmenlerin bilimsel epistemolojik } \\
\text { inançlarının tüm boyutları için anlamlı farklıllk bulunduğu tespit edilmiştir. Fizik, kimya } \\
\text { ve biyoloji öğretmenlerinin eğitim felsefesi tercihleri ile bilimsel epistemolojik inançları } \\
\text { arasında ilişki Pearson katsayısı ile araştırılmış ve bu unsurlar arasında ilişki bulunduğu } \\
\text { görülmüs̆tür. }\end{array}$ & 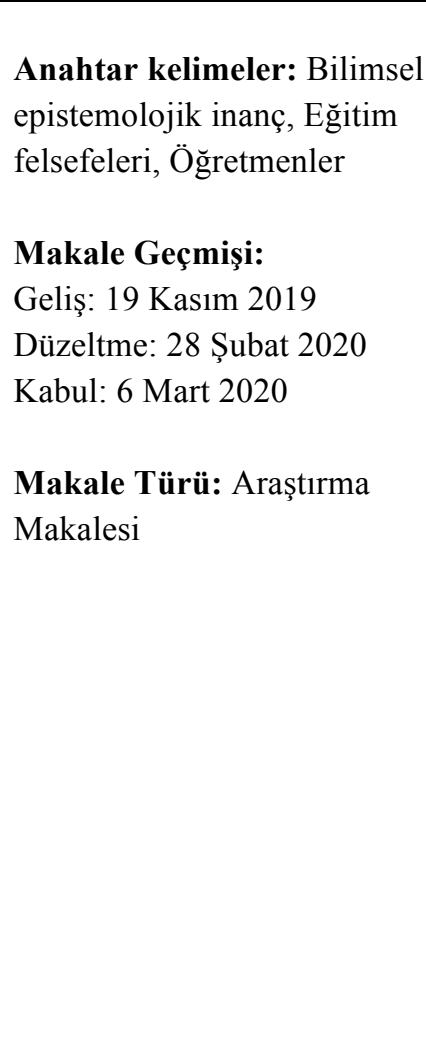 \\
\hline
\end{tabular}


Examining Science Philosophy Preferences and Scientific Epistemological Beliefs of Physics,

\section{Chemistry and Biology Teachers Regarding to Several Variables}

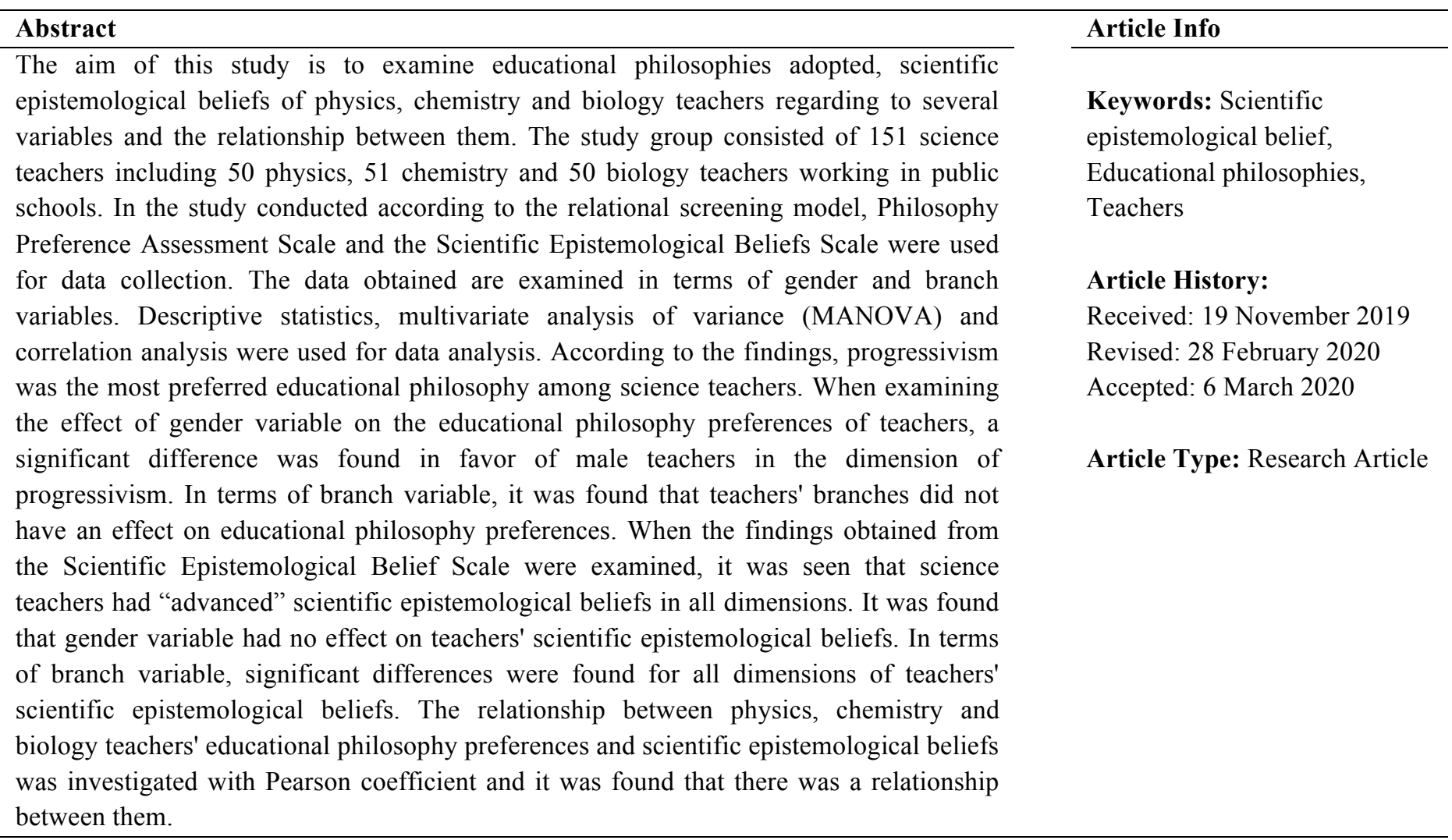




\section{Extended Summary}

\section{Introduction}

Educational philosophy is defined as a set of disciplinary or systematic concepts that shapes educational policies and controls these policies in terms of consistency and meaning. Teachers determine the teaching methods they will use, how to organize the classroom environment, and which kind of teacher role they choose according to the opinions in the philosophy of education they choose. Epistemological beliefs, on the other hand, are a set of beliefs about the nature of knowledge. The epistemological understanding of the individual affects his view of what knowledge is, how it is learned, taught and produced based on reality. It has been demonstrated in the literature that this perspective plays a role in the teaching of scientific knowledge and the regulation of the educational environment.

Considering the effects of teachers on their behaviors in the classroom, it is thought that there may be a relationship between their philosophical preferences and epistemological beliefs. There are many studies in the literature to determine the preferred educational philosophy and epistemological beliefs of teachers. However, it is seen that these studies have examined the philosophical preferences and scientific epistemological beliefs of the teachers separately. A limited number of studies examining the relationship between them have been reached.

As a common aspect of these studies, the same data collection tool was used in all of them. The working groups of these studies are social science teachers. In this study, science teachers were selected as the study group. In this respect, it is thought that the research will contribute to the literature with both the use of different measurement tools and the selection of different working groups.

In this context, it is aimed to determine the relationship between science epistemological beliefs and educational philosophies of science teachers. For this general purpose, the following questions were sought:

1. What are the philosophical preferences and scientific epistemological beliefs of science teachers?

2. Is there a difference between science teachers' philosophical preferences and scientific epistemological beliefs by gender and branches?

3. Is there a relationship between the epistemological beliefs of science teachers and their educational philosophies?

\section{Method}

In the research, relational screening model was used. The study group consists of 151 science teachers who work in public schools in Ankara. 89 of the teachers were female and 62 were male. 50 of them are physics, 51 of them are chemistry and 50 of them are biology teachers.

"Philosophy Preference Assessment Scale" (PPAS) and "Scientific Epistemological Beliefs Scale" (SEBS) were used for data collection. PPAS was developed by Wiles and Bondi (1993) and the Turkish adaptation was made by Doğanay and Sarı (2003). It consists of 5 dimensions: prennealism, idealism, realism, progressivism, existentialism. SEBS was developed by Conley, Pintrich, Vekiri and Harrison (2004). It was adapted by Özkan (2008). It consists of four dimensions: the source of information, the accuracy of information, the development of information and justification of information.

Data were analyzed using descriptive statistics and multivariate analysis of variance (MANOVA), since the effect of multiple independent variables on multiple dependent variables was investigated. Pearson Correlation Coefficient was used to determine the relationship between teachers' philosophical preferences and scientific epistemological beliefs.

\section{Results and Discussion}

According to the findings obtained from PPAS, the educational philosophies of science teachers participated in; experimentalism, realism, permanentism, idealism and existentialism, respectively. When the effect of the gender variable on the philosophical preferences of science teachers was examined, a significant difference was found between male and female teachers in "experimentalism" dimension. Male teachers had higher scores than women. The other dimensions of the scale did not differ according to gender. When the effect of the branch variable was examined, it was seen that there was no significant difference between the adopted educational philosophies and the branches. 
The findings obtained from SEBS showed that teachers had developed beliefs in all dimensions of SEBS. When the effect of gender on the SEBS scores was examined, no statistically significant difference was found between male and female teachers. This result is similar to the studies in the literature. When the effect of the branch variable on SEBS scores was investigated, a significant difference was found for all dimensions. There was a significant difference between biology-chemistry teachers in favor of biology teachers in terms of source of information. There was a significant difference between the physics-chemistry teachers in favor of chemistry teachers and the biologyphysics teachers in favor of biology teachers in terms of accuracy of knowledge. The significant difference between biology-chemistry teachers in the development of knowledge seemed to be in favor of biology teachers. In the justification of the information, a significant difference was found between biology-physics teachers and biologychemistry teachers.

The relationship between science teachers' preferred educational philosophies and their scientific epistemological beliefs was analyzed. There was no relationship between the source of knowledge and accuracy of knowledge and the philosophical preferences of teachers. A low-level positive correlation was found between the development of knowledge dimension and prennealism, realism and progressivism. On the other hand, there was a low-level positive correlation between the reasoning of knowledge and realism and experimentalism.

It was an unexpected result of the study that both traditional and classical currents were positively correlated with these dimensions. The results showing that there is a positive relationship between epistemological beliefs and educational philosophies seem to be opposite to each other are also seen in the literature. This is due to the fact that the study group was educated in a traditional way. Even though they are familiar with contemporary approaches, it may be because they have not completely abandoned their established ideas and understanding they grew up in. 


\section{Giriş}

İnsanlık tarihinde gerilere gidildikçe bilimle felsefenin de insanla birlikte var olduğu hissedilmektedir. Taş devrinde aletlerin amaca uygun olarak tasarlanmaları, ateşin kontrollü kullanılması bu düşünceyi desteklemektedir. Bilim ve felsefe tarih boyunca iki kardeş gibi, zaman zaman birbirine destek olarak ilerlemiş, otoriteye birlikte başkaldırmış; zaman zaman birbirine sırtını dönmüş, birbirine üstünlük sağlama çabası içerisine girmiştir. İlkçağda bilim ve felsefe tek vücutta varlığını sürdürürken, ortaçağ ile birlikte öncelikle doğa bilimleri ve daha sonra diğer bilim dalları felsefeden ayrılmaya başlamıştır. Felsefenin içerisinde zamanla bilgi felsefesi (epistemoloji), eğitim felsefesi gibi alt dallar ortaya çıkmıştır.

Eğitim felsefesi bireyin, karar verme sürecinde kendisine kılavuzluk eden, eğitimin amacı ve değeri ile ilgili sahip olduğu düşünceler seti olarak tanımlanmıştır (Gunzenhauser, 2003:52). Daha açık bir ifadeyle eğitim felsefesi; eğitim politikalarına yön veren varsayım, inanç, karar ve ölçütleri inceleyen, bu politikaları ve geliştirilen uygulamaları tutarlılık ve anlam yönünden kontrol eden bir disiplin ya da sistemli kavramlar bütünüdür (Biçer, Er, \& Özel, 2013). Eğitim felsefelerinin sınıflandırılmasına yönelik alanyazında farklı önerilere rastlanmaktadır. Bazı çalışmalarda, eğitim felsefelerinin daimicilik, esasicilik, ilerlemecilik ve yeniden kurmacılık olarak dört başlık altında toplandığ1 görülmektedir (Aybek \& Aslan, 2017; Gutek, 2014; Ornstein \& Hunkins, 2012). Apps (1973), eğitim felsefelerini daimicilik, esasicilik, ilerlemecilik, yeniden kurmacılık ve varoluşçuluk olarak sınıflandırmıştır. Ancak bu felsefelerin bazılarının, genel felsefi akımların bir kolu olduğu görülmektedir. Örneğin ilerlemecilik (diğer adıyla deneyselcilik), doğacılık ve yeniden kurmacılık pragmatizm kaynaklı (Aybek \& Aslan, 2017; Duman \& Ulubey, 2008; Sönmez, 2011); esasicilik idealizm ve realizm kaynaklı (Aybek \& Aslan, 2017; Duman \& Ulubey, 2008; San Mateo \& Tangco, 2003) olarak ortaya çıkmıştır. Bu durumu dikkate alan Wiles ve Bondi (1993, 2007), eğitim felsefelerini beş başlık altında toplamış; yapılandırılmış olandan esnek olana doğru, daimicilik (prennializm), idealizm, realizm, deneyselcilik (experimentalizm) ve varoluşçuluk (existentializm) olarak sıralamıştır. Alanyazında son yıllarda yapılan çalışmalara bakıldığında, en fazla kabul gören sınıflandırmanın bu olduğu görülmektedir (Aslan, 2014; Doğanay, 2011; Doğanay \& Sar1, 2003; Duman, 2008; Özba, 2015; Özbaş, 2015; Yapıc1, 2013; Yokuş, 2016). Bu araştırmada kullanılan "Felsefi Tercih Değerlendirme Ölçeği” de felsefi akımları bu beş başlık altında ele almıştır.

Eğitim sistemine ilişkin sorunları ve çözüm yöntemlerini inceleyen eğitim felsefesi, farklı akımlar tarafından farklı bakış açılarıyla değerlendirilmiştir. Daimicilik, temsilcilerinden birinin Platon olduğu en eski eğitim felsefesidir (Cevizci, 2015; Çalışkan, 2013). İnsanlara hemen her yerde kalıcı bir öneme sahip olan şeylerin, insanı insan yapan değerlerin, evrensel ilkelerin öğretilmesi gerektiğini iddia eder. Daimicilere göre insan, önce insan sonra mühendis ya da işçi olmalıdır (Cevizci, 2015, s.192). Eğitim öğretmen merkezlidir. Okul, insanın zihinsel potansiyelini geliştirmeyi amaçlayan toplumsal bir kurumdur (Gutek, 2001) ve kültürü etkili bir şekilde yeni kuşaklara aktarmakla görevlidir (Demirel, 2002, 24-25).

İdealizme göre bilgi dışarıda değil, insanların zihnindedir. İdealist eğitimde birey için en önemli hedef insanın özüne dönerek akılda bulunan gerçek bilgiyi kullanmasıdır (Sönmez, 2011). Sayısal dersler yerine sosyal temalı derslere ağırlık verilmektedir (Tozlu, 2003). Eğitim öğretmen merkezlidir ve öğretmenin görevi öğrenciyi yönlendirerek düşünsel becerilerini geliştirmektir (Cevizci, 2015).

En önemli temsilcisi Aritoteles olan realizmde eğitimin amacı, insanı insan yapan aklı olabildiğince güçlendirmektir (Cevizci, 2015). Sınıflar katı disiplinli, öğrenciler pasiftir. Öğretmenin görevi öğrencilere gerçeğin bilgisini olduğu gibi sunmak ya da araştırma ve gözlem ortamı oluşturmaktır (Wiles \& Bondi, 2007: 44).

Temelleri pragmatizme dayanan deneyselcilik öğrencinin pasif rolüne karşı çıkar. Eğitimin amacı, dünyanın sürekli değişen olguları hakkında nasıl bilgi sahibi olunacağını öğretmek ve öğrencinin topluma etkin bir şekilde katılmasını sağlamaktır (Ergün, 2011; Sönmez, 2011). Öğretmen öğrencilerin kendilerini geliştireceği, yaparak yaşayarak öğrenme ortamları oluşturarak onlara rehberlik eden bir rol üstlenmelidir (Kıncal, 2006; Sönmez, 2011).

Varoluşçuluk, insana önem veren, insanı merkeze alan ve insanın özgürleşmesini amaçlayan bir felsefedir. Eğitimin amac1, bireyin kendini gerçekleştirebilmesine yardımcı olmaktır (Ergün, 2011). Öğretmen bireyleri kendi doğrularını aramak için teşvik etmeli, bireyselliklerini ifade edecekleri bir öğretim ortamı oluşturmalıdır (Gutek, 2001).

Öğretmenlerin kullanacakları öğretim yöntemlerine karar verebilmeleri için belli bir eğitim felsefesine sahip olmaları gerekmektedir (Campbell, 1990). Elisasser'a (2008) göre felsefe, pedagoji bilgisini bir bağlam içerisine yerleştirmek suretiyle öğretme-öğrenme sürecine etki etmektedir. Öğretmenlerin sınıf ortamını düzenlemesinde 
benimsedikleri eğitim felsefesinde öğretmene biçilen rol ön plana çıkmaktadır (Denessen, 2000). Öğretmenlerin sahip oldukları felsefi inançların sınıftaki davranışlarını ve öğrenme ortamını nasıl yapılandırdıklarını gösteren araştırmalar bulunmaktadır (Austin \& Reinhardt, 1999; Brown \& Rose, 1995; Kagan, 1992). Ayn1 zamanda bu inançlar öğretmenlere, öğretim programlarının temelini anlamalarında ve etkinlikleri uygulamalarında da yardımcı olmaktadır (Karakuş, 2006 ). Alanyazında öğretmenler ve öğretmen adaylarıyla yapılan çalışmalarda farklı eğitim felsefelerinin benimsendiği görülmektedir (Alkın-Şahin, Tunca, \& Ulubey, 2014; Beytekin \& Kad1, 2015; Beytekin, Kad1, \& Toprakçı, 2015; Çalışkan, 2013; Çoban, 2007; Doğanay, 2011; Doğanay \& Sarı, 2003; Duman, 2008; Ekiz, 2007; Geçici \& Yapıc1, 2008; Hayırsever \& Oğuz, 2017; İzalan, 2017; Kumral, 2015; Mansour, 2013; Meral, 2014; Sang, Valcke, Van Braak, \& Tondeur, 2009; Sapkova, 2013; Stipek, Givvin, Salmon, \& MacGyvers, 2001; Tuncel, 2004; Uğurlu \& Çalmaşur, 2017; Yapıc1, 2013; Yokuş, 2016).

Epistemoloji, felsefenin bilgiyi araştıran dalıdır. Epistemolojik inançlar ise bilginin kaynağını, doğruluğunu, sınırlarını, elde edilme biçimlerini sorgulayan bir disiplin; bilginin doğası ile ilgili inançlar bütünüdür (Duell \& Schommer-Aikins, 2001; Topdemir, 2008; s. 16). Bireyin epistemolojik anlayışı onun gerçekliğe, gerçekliğe dayalı olarak bilginin ne olduğuna, nasıl öğrenildiğine, öğretildiğine ve üretildiğine yönelik bakış açısını etkiler (Aksan \& Sözer, 2007; Schommer, 1990). Bu bakış açısının bilimsel bilginin öğretilmesinde ve eğitim ortamının düzenlenmesinde rol oynadığı alanyazında ortaya konulmuştur (Phan, 2008; Phillips, 2001). Schommer' a (1993) göre epistemolojik inançlar gelişmemiş (naive) ve gelişmiş (sophisticated) inançlar olarak ifade edilmektedir. Gelişmemiş inançlara sahip bireyler öğrenmenin doğuştan gelen bir yetenek olduğu, bilginin ancak bir otorite tarafindan öğrencilere aktarılabileceği düşüncesini benimsemektedirler. Gelişmiş inançlara sahip olanlarda ise, öğrenme yeteneğinin geliştirilebileceği, bilginin akıl, sezgi, gözlem gibi çeşitli kaynaklara dayanılarak birey tarafından oluşturulduğu inancı hakimdir (Deryakulu \& Büyüköztürk, 2005). Bu sebeplerden ötürü öğretmenlerin epistemolojik inançlarını bilmek önem taşımaktadır.

Alanyazın incelendiğinde öğretmen adaylarının (Ayaz, 2009; Aypay, 2011; Belet \& Güven, 2011; Biçer, Er, \& Özer, 2013; Chan, 2004; Cheng Chan, Tang, \& Cheng, 2009; Eroğlu \& Güven, 2006; Sapanc1 2012) ve öğretmenlerin (Angeli \& Valanides, 2012; Deryakulu, 2004; Karhan, 2007; Trakulphadetkrai, 2012) epistemolojik inançlarını belirleyen çalışmalar görülmektedir. Yapılan çalışmalarda epistemolojik inançlar üzerinde, cinsiyet, yaş, öğrenim görülen alan, eğitim düzeyi, öğretim yaklaşımı, içinde yaşanılan kültür faktörlerinin etkili olduğu belirlenmiş̧tir (Aydın \& Gür, 2017; Bath \& Smith, 2009; Baxter Magolda, 2004; Chan \& Elliott, 2002; Conley, Pintrich, Vekiri, \& Harrison, 2004; Enman \& Lupart, 2000; Er, 2013; Eroğlu \& Güven, 2006; Gürol, Altunbas, \& Karaaslan, 2010; Karabulut \& Ulucan, 2012; Kaymak, 2010; Sadıç, Çam, \& Topçu, 2012; Schommer, 1998; Schommer-Aikins, Duell, \& Hutter, 2005; Terzi, 2005; Tümkaya, 2012; Yeşilyurt, 2013).

Öğretmenlerin sınıftaki davranışlarına etkileri göz önünde bulundurulduğunda felsefi tercihleri ve epistemolojik inançları arasında bir ilişkinin olabileceği düşünülmektedir. Alanyazında öğretmenlerin tercih ettikleri eğitim felsefelerini ve epistemolojik inançlarını belirlemeye yönelik çok sayıda çalışma bulunmasına rağmen, bu iki unsurun ayrı ayrı incelendiği görülmektedir. Aralarındaki ilişkiyi inceleyen sınırlı sayıda çalışmaya ulaşılmıştır (Biçer, Er, \& Özel, 2013; Kahramanoğlu \& Özbakış, 2018; Önen, 2011).

Alanyazındaki bu çalışmaların bulgularında epistemolojik inanç ölçeğinin boyutlarından biri olan öğrenmenin çabaya bağlı olduğuna inanç ile deneyselcilik (ilerlemecilik), varoluşçuluk ve yeniden kurmacılık arasında yüksek düzeyde pozitif ilişki (Biçer, Er, \& Özel, 2013) ve orta düzeyde negatif ilişki (Kahramanoğlu \& Özbakış, 2018) bulunmuştur. Ölçeğinin ikinci boyutu olan öğrenmenin yeteneğe bağlı olduğuna inanç ile esasicilik arasında yüksek düzeyde pozitif (Biçer, Er, \& Özel, 2013) ve orta düzeyde pozitif (Kahramanoğlu \& Özbakış, 2018) ilişkiler saptanmıştır. Aynı boyut ile deneyselcilik, varoluşçuluk ve yeniden kurmacılık arasında düşük düzeyde negatif (Kahramanoğlu \& Özbakış, 2018); daimicilik ve yeniden kurmacıllk arasında pozitif (Önen, 2011); deneyselcilik, varoluşçuluk ve daimicilik arasında negatif yönde (Biçer, Er, \& Özel, 2013) ilişkiler görülmüştür. Üçüncü boyutu olan tek bir doğrunun var olduğuna inanç ile daimicilik ve esasicilik arasında düşük düzeyde pozitif (Kahramanoğlu \& Özbakış, 2018); esasicilik ve yeniden kurmacılık arasında yüksek düzeyde pozitif (Biçer, Er, \& Özel, 2013) ve daimicilik arasında pozitif yönde (Biçer, Er, \& Özel, 2013; Önen, 2011) ilişkiler saptanmıştır.

Araştırma bulguları arasındaki çelişkiler bulunması ve araştırma sayısının azlığı bu konuda genel bir yargıya varmaya olanak sağlamamaktadır. Çalışmaların ortak yönü olarak, üçünde de (Biçer, Er, \& Özel, 2013; Kahramanoğlu, \& Özbakış, 2018; Önen, 2011) veri toplama aracı olarak "Eğitim İnançları Ölçeği” (Yılmaz, Altınkurt, 
\& Çokluk, 2011) ve "Epistemolojik İnanç Ölçeği” (Schommer, 1990) kullanıldığı görülmektedir. Bu araştırmaların çalışma gruplarını sosyal bilgiler öğretmenleri (Biçer, Er, \& Özel, 2013), sınıf öğretmenleri (Kahramanoğlu \& Özbakış, 2018) ve öğretmen adayları (Önen, 2011) oluşturmaktadır. Bu çalışmada ise çalışma grubu olarak fen bilimleri öğretmenleri seçilmiştir. Bu yönüyle, hem farklı ölçme araçları kullanımı hem de farklı çalışma grubu seçimiyle, araştırmanın alana katkı sağlayacağı düşünülmektedir.

$\mathrm{Bu}$ bağlamda araştırmada fizik, kimya ve biyoloji öğretmenlerinin bilimsel epistemolojik inançlarını, benimsedikleri eğitim felsefelerini ve bu unsurlar arasındaki ilişkiyi belirlemek amaçlanmıştır. Bu genel amaç doğrultusunda;

1. Fizik, kimya ve biyoloji öğretmenlerinin felsefi tercihleri ve bilimsel epistemolojik inançları nelerdir?

2. Fizik, kimya ve biyoloji öğretmenlerinin felsefi tercihleri ve bilimsel epistemolojik inançları arasında cinsiyete ve branşlara göre fark var mıdır?

3. Fizik, kimya ve biyoloji öğretmenlerinin epistemolojik inançları ve benimsedikleri eğitim felsefeleri arasında ilişki var mıdır? sorularına cevap aranmıştır.

\section{Yöntem}

Araştırmada ilişkisel tarama modeli kullanılmıştır. Genel tarama modeli türlerinden ilişkisel tarama modeli; iki ya da daha fazla değişken arasında, birlikte değişimin varlığını veya derecesini belirlemeyi amaçlayan bir araştırma modelidir (Cohen, Manion, \& Morrison, 2000; Fraenkel \& Wallen, 2009; Karasar, 2012). Bu model gerçek bir nedensonuç ilişkisi vermemekle birlikte, bir değişkendeki durumun bilinmesi halinde ötekinin kestirilmesine olanak sağlamaktadır (Karasar, 2012).

\section{Evren ve Örneklem}

Araştırmanın evrenini, 2018-2019 eğitim-öğretim yılında Ankara ili Çankaya ve Yenimahalle ilçelerinde MEB'e bağlı Anadolu liselerinde görev yapan toplam 229 fizik, kimya ve biyoloji öğretmeni oluşturmaktadır. Araştırma, hedef evrenin tümüne ulaşmanın mümkün olmaması nedeniyle evrenden seçilen örneklem üzerinde yürütülmüştür. Örneklem büyüklüğünün belirlenmesinde Krejcie ve Morgan'ın önerdiği tablo kullanılmıştır. Bu tabloda anlamlılık düzeyi 0.05 ve hata oranı $( \pm) 0.05$ kabul edildiğinde, evren hacminin 230 olması durumunda örneklem büyüklüğü minimum 144 olarak belirtilmiştir (Aktaran Kılıç \& Ural, 2004). Örneklemin oluşturulmasında "uygun örnekleme" yöntemi uygulanmıştır. Ölçme araçlarının uygulanması aşamasında geri dönüşlerde meydana gelen kayıplar nedeniyle her iki ölçme aracını da cevaplamış olan öğretmenlere örneklemde yer verilmiştir. Buna göre araştırmanın örneklemini ulaşılabilen, anket uygulamasına katılmayı kabul eden ve uygulamanın yapıldığı zaman aralığında görevinde olan 151 fizik, kimya ve biyoloji öğretmeni oluşturmaktadır. Çalışmada incelenen bağımsız değişkenler branş ve cinsiyettir. Çalışma grubunun bu değişkenlere göre dağılımı Tablo 1'de görülmektedir.

Tablo 1. Araştırmada incelenen bağımsız değişkenlere göre örneklemdeki frekans ve yüzdelikler

\begin{tabular}{lcccccccc}
\hline & \multicolumn{3}{c}{ Fizik } & \multicolumn{2}{c}{ Kimya } & \multicolumn{2}{c}{ Biyoloji } & \multicolumn{2}{c}{ Toplam } \\
\cline { 2 - 9 } & f & \% & f & \% & f & \% & f & \% \\
\hline Kadın & 30 & 19,9 & 32 & 21,2 & 27 & 17,9 & 89 & 58,9 \\
Erkek & 20 & 13,2 & 19 & 12,6 & 23 & 15,2 & 62 & 41,1 \\
Toplam & 50 & 33,1 & 51 & 33,8 & 50 & 33,1 & 151 & 100,0 \\
\hline
\end{tabular}

Tablo 1'de görüldügü gibi öğretmenlerin 89'u (\%58,9) kadın, 62'si $(\% 41,1)$ erkektir; yaş ortalamaları 37'dir (min: 26; maks: 48). Çalışmaya en fazla katılımın kimya öğretmenlerinden $(\% 33,8)$ olduğu, bunu fizik $(\% 33,1)$ ve biyoloji $(\% 33,1)$ öğretmenlerinin takip ettiği görülmektedir.

\section{Veri Toplama Araçları}

Felsefi Tercih Değerlendirme Formu (FTDF): Fizik, kimya ve biyoloji öğretmenlerinin benimsedikleri eğitim felsefesini belirlemek için Wiles ve Bondi (1993) tarafından geliştirilen "Felsefi Tercih Değerlendirme Formu" (FTD) (Philosophy Preference Assesment) kullanılmıştır. Ölçeğin Türkçe uyarlaması Doğanay ve Sarı (2003) tarafından 
yapılmıştır. FTDF, eğitim felsefelerini belirlemeye yönelik 40 maddeden oluşan, 5 dereceli Likert tipi (1-Kesinlikle Katılmıyorum, 2-Katılmıyorum, 3-Karasızım, 4-Katılıyorum, 5-Kesinlikle Katılıyorum) bir ölçektir. Daimicilik, İdealizm, Realizm, Deneyselcilik, Varoluşçuluk olmak üzere 5 alt boyuttan oluşmaktadır. Her bir alt boyuta ait 8 madde bulunmaktadır. Cronbach Alfa güvenirlik katsayısı; daimicilik için ,65, idealizim için ,60, realizm için ,78, deneyselcilik için ,75 ve varoluşçuluk içinde ,64 olarak hesaplanmıştır. Ölçekten bir toplam puan elde edilmemekte, katılımcıların her bir eğitim felsefesini ne kadar benimsedikleri görülmektedir. Bir boyuttan alınan puanın yüksek olması katılımcıların o alt ölçekteki eğitim felsefesine inandığını ve benimsediğini göstermektedir.

Bilimsel Epistemolojik İnanç Ölçeği (BEİÖ): Fizik, kimya ve biyoloji öğretmenlerinin bilimsel epistemolojik inançlarını ölçmek için Conley, Pintrich, Vekiri ve Harrison (2004) tarafından geliştirilmiş olan "Bilimsel Epistemolojik İnanç Ölçeği (BEİÖ)” kullanılmıştır. Türkçe’ye uyarlaması Özkan (2008) tarafından yapılmıştır. Bu ölçek 26 maddeden oluşan 5'li Likert tipi (5-Kesinlikle kat1lıyorum, 4-Katılıyorum, 3-Karasızım, 2-Katılmıyorum, 1Kesinlikle katılmıyorum) bir ölçektir. Doğrulayıcı faktör analiziyle (DFA) doğrulanan ölçek $(\chi 2 / \mathrm{df}=1,44$; CFI=0,95; $\mathrm{TLI}=0,93$ ve RMSEA=0,04), bilginin kaynağı, bilginin kesinliği, bilginin gelişimi ve bilginin gerekçelendirilmesi şeklinde 4 alt boyuta sahiptir. Bu boyutlar için Cronbach Alpha değerleri ,69; ,67; ,70 ve ,83 olarak hesaplanmıştır

BEİÖ'nün bilginin kaynağı boyutu bireylerin bilginin sahibinin dışarıdaki bir otorite olup olmadığı inancını ölçmektedir (Özkan \& Tekkaya, 2011). Bu boyuttan alınan yüksek puanlar bireylerin bilginin öğrenen tarafından oluşturulduğuna inandığını göstermektedir. Bilginin kesinliği boyutu, tek bir doğrunun var olup olmadığına yönelik inançları belirlemeye yöneliktir (Özkan, 2008). Bu boyuttaki puanların yüksek olması doğrunun birden fazla olabileceğine dair inançların bulunduğu göstermektedir. Bilginin gelişimi, bilginin değişebileceğine yönelik inançlara yöneliktir (Özkan \& Tekkaya, 2011). Bu boyuttaki yüksek puanlar bilginin gelişen ve değişen bir doğası olduğuna inanıldığına işaret etmektedir. Bilginin gerekçelendirmesi, bireylerin bilgileri olduğu gibi kabul edip etmediklerini ölçmektedir (Özkan \& Tekkaya, 2011). Bu boyuttaki yüksek puanlar bireylerin kanıtların ve uzman görüşlerinin eleştirel bir şekilde yargılanması gerektiğine inandığını göstermektedir.

\section{Verilerin Analizi}

Veri analizinde kullanılacak testlerin belirlenmesi için öncelikle elde edilen verilerin normal dağılım gösterip göstermediği incelenmiştir. Ölçeklerden alınan puanların ortalamaları, Kolmogorov Smirnov testi sonuçları ve çarpıklık-basıklık değerleri incelenmiştir. Puanların dağılımında aritmetik ortalama, medyan ve mod birbirine yakın olması (Büyüköztürk, 2012); çarpıklık katsayısının çarpıklık standart hatasına, aynı şekilde basıklık katsayısının basıklığın standart hatasına bölündüğünde sonuçların -1,96 ile +1,96 arasında olması (Can, 2014) normal dağılımın bir göstergesi olarak kabul edilir. Tablo 2 incelendiğinde bu işlem sonu çıkan değerlerin bu aralıkta kaldı ğı görülmektedir. Ölçeklerden elde edilen toplam puanlara ait merkezi eğilim ölçüleri Tablo 2'de verilmiştir.

Verilerin analizinde betimsel istatistik ve birden fazla bağımsız değişkenin birden fazla bağımlı değişken üzerindeki etkisi araştırıldığından çok değişkenli varyans analizi (MANOVA) kullanılmıştır. MANOVA yapmadan önce varyansların homojenliğinin test edilmesi, çok değişkenli normallik varsayımının karşılanması, çoklu doğrusal bağlantının olmaması ve varyans-kovaryans matrislerinin homojenliğinin sağlanması gerekmektedir. Yapılan analizler sonucunda, tüm varsayımların sağlandığı tespit edilmiştir.

MANOVA sonucunda, anlamlı fark tespit edilen değişkenler için, bulunan anlamlı farkın farkın büyüklüğünü belirlemek amacıyla etki değerine (effect size) bakılmıştır. Etki değerinin hesaplanmasında Eta kare değeri kullanılmıştır. Cohen'in sınıflamasına göre, bu değer 0,01- 0,06 arasında ise "küçük etki", 0,06 ile 0,14 arasında ise "orta düzeyde etki", 0,14 veya daha fazla ise "büyük etki” yorumu yapılır (Akbulut, 2011; Pallant, 2005).

Katılım düzeyleri belirlenirken puan aralıkları "aralık katsayısı $=(\mathrm{n}-1 / \mathrm{n})$ " formülüyle 0,80 bulunmuştur. Buna göre sonuçlar "Kesinlikle katılmıyorum (1,00 - 1,79), Katılmıyorum (1,80-2,59), Kısmen katılıyorum $(2,60$ - 3,39), Katılıyorum (3,40 - 4,19), Kesinlikle katılıyorum (4,20 - 5,00)" şeklinde belirlenmiştir.

Öğretmenlerin felsefi tercihleri ile sahip oldukları bilimsel epistemolojik inançlar arasındaki ilişkiyi belirlemede Pearson Korelasyon Katsayısı kullanılmıştır. Korelasyon analizinin ilişki ve kuvvetini belirlemede Büyüköztürk'ün (2012) belirttiği ölçütler (0,70- 1,00 “yüksek”; 0,69-0,30 “orta”; 0,29-0,00 “düşük”) kullanılmıştır. 
Tablo 2. Ölçeklerden alınan puanlara ait merkezi eğilim ölçüleri

\begin{tabular}{|c|c|c|c|c|c|c|c|c|c|c|c|}
\hline & Alt boyutlar & 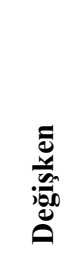 & $\mathbf{N}$ & & $\stackrel{\Xi}{E}$ & 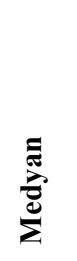 & 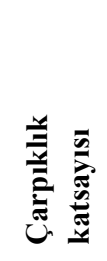 & 兰 & 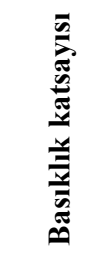 & 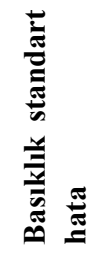 & 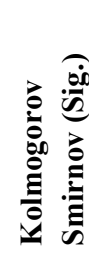 \\
\hline \multirow{15}{*}{ 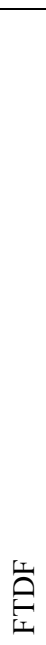 } & \multirow{3}{*}{ Daimicilik } & $\mathrm{K}^{*}$ & 89 & 3,83 & 4,00 & 3,88 & $-0,40$ & 255 & 0,99 & 506 & ,094 \\
\hline & & $\mathrm{E}^{*}$ & 62 & 3,88 & 4,38 & 4,00 & $-0,28$ & ,304 & 0,09 & ,599 &, 112 \\
\hline & & $\mathrm{T}^{*}$ & 151 & 3,85 & 4,00 & 3,88 & $-0,37$ & ,197 & 0,75 & ,392 & ,103 \\
\hline & \multirow{3}{*}{ İdealizm } & $\mathrm{K}$ & 89 & 3,67 & 3,88 & 3,75 & $-0,37$ &, 255 & 0,39 &, 506 &, 120 \\
\hline & & $\mathrm{E}$ & 62 & 3,74 & 3,50 & 3,75 & 0,05 & ,304 & $-0,27$ & ,599 & 090 \\
\hline & & $\mathrm{T}$ & 151 & 3,70 & 3,88 & 3,75 & $-0,17$ & ,197 & 0,12 & ,392 & ,103 \\
\hline & \multirow{3}{*}{ Realizm } & $\mathrm{K}$ & 89 & 3,84 & 3,75 & 3,75 & $-0,22$ &, 255 & 0,93 &, 506 & ,091 \\
\hline & & $\mathrm{E}$ & 62 & 3,88 & 3,88 & 3,88 & $-0,33$ & ,304 & 1,04 & ,599 & 090 \\
\hline & & $\mathrm{T}$ & 151 & 3,86 & 3,75 & 3,88 & $-0,26$ & 197 & 0,72 & ,392 & 090 \\
\hline & \multirow{3}{*}{ Deneyselcilik } & K & 89 & 4,04 & 4,00 & 4,13 & $-0,42$ & ,255 & 0,99 & ,506 &, 070 \\
\hline & & $\mathrm{E}$ & 62 & 4,24 & 4,25 & 4,25 & $-0,04$ & ,304 & $-0,23$ & ,599 &, 121 \\
\hline & & $\mathrm{T}$ & 151 & 4,12 & 4,13 & 4,13 & $-0,35$ & 197 & 1,22 & ,392 & ,096 \\
\hline & \multirow{3}{*}{ Varoluşçuluk } & $\mathrm{K}$ & 89 & 3,28 & 3,00 & 3,25 & 0,17 & 255 & 0,35 & ,506 & 060 \\
\hline & & $\mathrm{E}$ & 62 & 3,41 & 3,13 & 3,38 & 0,26 &, 304 & 0,50 & ,599 &, 120 \\
\hline & & $\mathrm{T}$ & 151 & 3,33 & 3,13 & 3,25 & 0,21 & 197 & 0,43 & ,392 & 098 \\
\hline \multirow{12}{*}{$\frac{0}{0}$} & \multirow{3}{*}{ Bilginin kaynağ } & $\mathrm{K}$ & 89 & 3,73 & 4,00 & 3,80 & $-0,14$ & 255 & $-0,40$ & 506 & 230 \\
\hline & & $\mathrm{E}$ & 62 & 3,94 & 4,00 & 4,00 & $-0,37$ &, 304 & $-0,90$ & ,599 &, 058 \\
\hline & & $\mathrm{T}$ & 151 & 3,82 & 4,00 & 3,80 & $-0,19$ & 197 & $-0,71$ & ,392 &, 106 \\
\hline & \multirow{3}{*}{ Bilginin kesinliği } & $\mathrm{K}$ & 89 & 3,78 & 4,00 & 3,80 & $-0,17$ &, 255 & $-0,29$ & ,506 & ,300 \\
\hline & & $\mathrm{E}$ & 62 & 3,89 & 4,00 & 4,00 & $-0,53$ & ,304 & 0,02 & ,599 & ,077 \\
\hline & & $\mathrm{T}$ & 151 & 3,83 & 4,00 & 3,80 & $-0,32$ & 197 & 0,11 & ,392 & 097 \\
\hline & \multirow{3}{*}{ Bilginin gelişimi } & $\mathrm{K}$ & 89 & 3,97 & 3,83 & 4,00 & $-0,38$ & 255 & 1,12 &, 506 &, 120 \\
\hline & & $\mathrm{E}$ & 62 & 4,07 & 4,17 & 4,17 & $-0,30$ &, 304 & 0,27 &, 599 &, 062 \\
\hline & & $\mathrm{T}$ & 151 & 4,02 & 3,83 & 4,00 & $-0,33$ & 197 & 0,67 & ,392 &, 100 \\
\hline & \multirow{3}{*}{ Bilginin gerekçelendirilmesi } & $\mathrm{K}$ & 89 & 4,20 & 4,22 & 4,22 & $-0,25$ &, 255 & 0,01 &, 506 &, 082 \\
\hline & & E & 62 & 4,19 & 4,44 & 4,33 & $-0,16$ & ,304 & 0,03 & ,599 &, 153 \\
\hline & & $\mathrm{T}$ & 151 & 4,20 & 4,22 & 4,22 & $-0,21$ & 197 & 0,08 & ,392 &, 100 \\
\hline
\end{tabular}

*K: Kadın, E: Erkek, T: Toplam

\section{Bulgular}

Araştırmadan elde edilen bulgular, "Fizik, kimya ve biyoloji öğretmenlerinin benimsedikleri eğitim felsefelerine yönelik bulgular", "Fizik, kimya ve biyoloji öğretmenlerinin epistemolojik inançlarına yönelik bulgular" ve "Fizik, kimya ve biyoloji öğretmenlerinin benimsedikleri eğitim felsefesi ile epistemolojik inançları arasındaki ilişkiye yönelik bulgular" başlıkları altında üç kısımda sunulmuştur.

\section{Fizik, Kimya ve Biyoloji Öğretmenlerinin Felsefi Tercihlerine Yönelik Bulgular}

Fizik, kimya ve biyoloji öğretmenlerinin FTDF'nin alt boyutlarından aldıkları puanlara ve bu boyutlara katılma düzeylerine ait betimsel analiz Tablo 3'te görülmektedir.

Tablo 3'ten öğretmenler arasında en fazla deneyselcilik felsefesinin benimsendiği ("katıllyorum" düzeyinde; $\overline{\mathrm{x}}=4,12 \pm, 42)$ görülmektedir. Diğer alt boyutlara katılımın realizm "kat1lıyorum" ( $\overline{\mathrm{x}}=3,86 \pm, 22)$, daimicilik "katılıyorum" ( $(\overline{\mathrm{x}}=3,85 \pm, 19)$, idealizm "katılıyorum" $(\overline{\mathrm{x}}=3,70 \pm, 28)$ ve varoluşçuluk "kismen katılmıyorum" $(\bar{x}=3,33 \pm, 29)$ düzeyinde olduğu görülmektedir. 
Tablo 3. Öğretmenlerin FTDF'sine ilişkin betimsel istatistik

\begin{tabular}{|c|c|c|c|c|c|c|}
\hline Alt boyut & $\mathbf{n}$ & & Ss & Min. & Maks. & Düzey \\
\hline Daimicilik & 151 & 3,85 & ,19 & 2,00 & 5,00 & Kat1liyorum \\
\hline İdealizm & 151 & 3,70 & ,28 & 2,38 & 4,88 & Kat1liyorum \\
\hline Realizm & 151 & 3,86 & ,22 & 2,13 & 5,00 & Kat1liyorum \\
\hline Deneyselcilik & 151 & 4,12 &, 42 & 2,50 & 5,00 & Kat1liyorum \\
\hline Varoluşçuluk & 151 & 3,33 & ,29 & 2,13 & 5,00 & Kismen kat1liyorum \\
\hline
\end{tabular}

Fizik, kimya ve biyoloji öğretmenlerinin FTDF alt boyutları ile cinsiyetlerine ilişkin tek faktörlü MANOVA sonuçları Tablo 4'te sunulmuştur.

Tablo 4. Fizik, kimya ve biyoloji öğretmenlerinin FTDF boyutları ile cinsiyetlerine ilişkin tek faktörlü MANOVA sonuçları

\begin{tabular}{|c|c|c|c|c|c|c|c|}
\hline \multirow{2}{*}{ Alt boyut } & \multicolumn{2}{|c|}{ Kadın } & \multicolumn{2}{|c|}{ Erkek } & \multirow{2}{*}{$F(1,149)$} & \multirow[b]{2}{*}{$\mathbf{p}$} & \multirow{2}{*}{$\eta 2$} \\
\hline & & SS & & SS & & & \\
\hline Daimicilik & 3,830 &, 054 & 3,880 &, 065 & ,356 &, 552 & - \\
\hline İdealizm & 3,670 & ,049 & 3,744 &, 058 & ,963 & ,328 & - \\
\hline Realizm & 3,846 &, 048 & 3,884 &, 057 & ,249 & ,618 & - \\
\hline Deneyselcilik & 4,043 & ,044 & 4,240 &, 053 & 8,232 &, $005 *$ &, 052 \\
\hline Varoluşçuluk & 3,283 &, 050 & 3,410 &, 060 & 2,658 & , 105 & - \\
\hline
\end{tabular}

Wilks Lambda Testi sonuçları, cinsiyet açısından öğretmenlerin FTDF boyutlarının doğrusal kombinasyonlarının anlamlı bir farklılık gösterdiğini ortaya koymuştur (Wilk's $\Lambda=, 915 ; \mathrm{F}_{1-149}=2,708 ; \mathrm{p}=, 023$ ). Tablo 4 'ten öğretmenlerin deneyselcilik $\left(\mathrm{F}_{1-149}=8,232 ; \mathrm{p}<, 05\right)$ boyutu için cinsiyetlerine göre erkek öğretmenlerin lehine anlamlı farklılık olduğu tespit edilmiştir. Diğer boyutlardan alınan puanların cinsiyet açısından anlamlı farklılık göstermediği görülmektedir. Etki değerine bakıldığında, öğretmenlerin felsefi tercihleri üzerinde cinsiyet değişkeni açısından belirlenen farkın küçük olduğu görülmektedir. Bu değere göre, cinsiyet değişkeni deneyselcilik boyutu için öğretmenlerin felsefi tercihleri üzerinde $\% 5,2$ 'lik bir etki büyüklüğüne sahiptir.

Fizik, kimya ve biyoloji öğretmenlerinin benimsedikleri eğitim felsefeleri üzerinde branşlarının etkisini belirlemek için tek faktörlü MANOVA yapılmıştır. MANOVA sayıltıları kontrol edildiğinde Box'ın M istatistiğine göre yayılma matrisinin homojenlik sayıltısının sağlanmadığ 1 tespit edilmiş̧ir $\left(F_{30-69360.695}=1,775, p=, 006\right)$. Çoklu varyans analizinde şartların tutturulamaması durumunda Wilk's Lambda değerinin yerine Pillai Trace değerinin yorumlanması önerilmektedir. Sonuçlar Tablo 5'te görülmektedir.

Tablo 5. Fizik, kimya ve biyoloji öğretmenlerinin FTDF boyutları ile branşlarına iliş̧kin tek faktörlü MANOVA sonuçları

\begin{tabular}{|c|c|c|c|c|c|c|c|c|}
\hline \multirow{2}{*}{ Alt boyut } & \multicolumn{2}{|c|}{ Fizik } & \multicolumn{2}{|c|}{ Kimya } & \multicolumn{2}{|c|}{ Biyoloji } & \multirow{2}{*}{$F(2,148)$} & \multirow{2}{*}{$\mathbf{p}$} \\
\hline & & SS & & SS & & SS & & \\
\hline Daimicilik & 3,892 & ,071 & 3,750 & ,071 & 3,910 & ,071 & 1,529 & 22 \\
\hline İdealizm & 3,737 &, 065 & 3,672 &, 065 & 3,693 & ,065 & ,268 & ,76 \\
\hline Realizm & 3,920 &, 064 & 3,794 &, 063 & 3,872 &, 064 & 1,009 &, 36 \\
\hline Deneyselcilik & 4,110 &, 060 & 4,066 &, 059 & 4,197 &, 060 & 1,247 &, 29 \\
\hline Varoluşçuluk & 3,433 & ,066 & 3,269 &, 066 & 3,305 & ,066 & 1,675 & ,19 \\
\hline
\end{tabular}

Pillai Trace Testi sonuçları branş açısından fizik, kimya ve biyoloji öğretmenlerinin FTDF alt boyutlarının doğrusal kombinasyonlarının anlamlı bir farklılık göstermediğini ortaya koymuştur (Pillai Trace $(\lambda)=, 071, \mathrm{~F}_{6-}$ ${ }_{143}=1,073, \mathrm{p}=$,383). Tablo 4'te görüldüğ̈̈ üzere, daimicilik $\left(\mathrm{F}_{2-148}=1,529 ; \mathrm{p}>, 05\right)$, idealizm $\left(\mathrm{F}_{2-148}=, 268 ; \mathrm{p}>, 05\right)$, realizm $\left(\mathrm{F}_{2-148}=1,009 ; \mathrm{p}>, 05\right)$, deneyselcilik $\left(\mathrm{F}_{2-148}=1,247 ; \mathrm{p}>, 05\right)$ ve varoluşçuluk $\left(\mathrm{F}_{2-148}=1,675 ; \mathrm{p}>, 05\right)$ ile ögretmenlerin branşları arasında anlamlı farklılık yoktur. 


\section{Fizik, Kimya ve Biyoloji Öğretmenlerinin Epistemolojik İnançlarına Yönelik Bulgular}

Fizik, kimya ve biyoloji öğretmenlerinin BEİÖ'den aldıkları puanların betimsel analizi Tablo 6'da görülmektedir.

Tablo 6. Fizik, kimya ve biyoloji öğretmenlerinin BEİÖ boyutlarından aldıkları puanlara ve bu boyutlara katılma düzeylerine ait betimsel analizi

\begin{tabular}{|c|c|c|c|c|c|c|}
\hline Alt boyut & $\mathbf{n}$ & & Ss & Min. & Maks. & Düzey \\
\hline Bilginin kaynağ & 151 & 3,82 & ,73 & 2,00 & 5,00 & Gelişmiş \\
\hline Bilginin kesinliği & 151 & 3,83 & ,65 & 2,00 & 5,00 & Gelişmiş \\
\hline Bilginin gelişimi & 151 & 4,02 &, 59 & 1,33 & 5,00 & Gelişmiş \\
\hline Bilginin gerekçelendirilmesi & 151 & 4,20 & ,68 & 1,22 & 5,00 & Gelişmiş \\
\hline
\end{tabular}

Tablo 6 incelendiğinde Fizik, kimya ve biyoloji öğretmenlerinin bilimsel epistemolojik inanç düzeylerinin her boyut için "gelişmiş" olduğu görülmektedir. En yüksek ortalama puan bilginin gerekçelendirilmesi boyutuna $(\overline{\mathrm{x}}=4,20 \pm, 68)$ aittir. Diğer boyutların puanları ise bilginin kaynağı için $(\overline{\mathrm{x}}=3,81 \pm, 73)$, bilginin kesinliği için $(\overline{\mathrm{x}}=3,83 \pm, 65)$, bilginin gelişimi için $(\overline{\mathrm{x}}=4,02 \pm, 59)$ olmuştur.

Fizik, kimya ve biyoloji öğretmenlerinin BEÏÖ'den aldıkları puanlar arasında cinsiyetlerine göre anlamlı farklılık olup olmadığını incelemek için yapılmış olan tek faktörlü MANOVA sonuçları Tablo 7'de sunulmuştur.

Tablo 7. Fizik, kimya ve biyoloji öğretmenlerinin BEIÖ boyutları ile cinsiyetlerine ilişkin tek faktörlü MANOVA sonuçları

\begin{tabular}{|c|c|c|c|c|c|c|}
\hline \multirow{2}{*}{ Alt boyut } & \multicolumn{2}{|c|}{ Kadın } & \multicolumn{2}{|c|}{ Erkek } & \multirow{2}{*}{$F(1,149)$} & \multirow{2}{*}{$\mathbf{p}$} \\
\hline & & SS & & SS & & \\
\hline Bilginin kaynağ 1 & 3,726 & 077 & 3,935 & ,093 & 3,009 & ,085 \\
\hline Bilginin kesinliği & 3,780 & 070 & 3,894 & 083 & 1,009 & ,296 \\
\hline Bilginin gelişimi & 3,977 &, 063 & 4,070 & ,076 &, 887 & ,348 \\
\hline Bilginin gerekçelendirilmesi & 4,202 & 072 & 4,190 & 087 &, 011 & ,916 \\
\hline
\end{tabular}

Analize geçmeden önce varyansların eşitliği varsayımı, Levene testi, kovaryans homojenlik varsayımı, Box M testi kullanılarak incelenmiştir. Box M istatistiğine göre yayılma matrisinin homojenlik sayıltısının sağlandığ tespit edilmiştir (Box $\left.M=16,116 ; \mathrm{F}_{10-80782.205}=1,563 ; \mathrm{p}=, 111\right)$. Araştırma sorusunu test etmek için Wilks' Lambda istatistiği kullanılmıştır. Wilks Lambda Testi sonuçları cinsiyet açısından öğretmenlerin bilimsel

epistemolojik inançlarına ait alt boyutlarının doğrusal kombinasyonlarının anlamlı bir farklılık göstermediğini ortaya koymuştur (Wilk's $\left.\Lambda=, 958 ; \mathrm{F}_{6-144}=1,595 ; \mathrm{p}=, 179\right)$. Tablo 7'de öğretmenlerin cinsiyetleri ile bilginin kaynağ $\left(\mathrm{F}_{1-}\right.$ $\left.{ }_{149}=2,107 ; \mathrm{p}>, 05\right)$, bilginin kesinliği $\left(\mathrm{F}_{1-149}=2,025 ; \mathrm{p}>, 05\right)$, bilginin gelişimi $\left(\mathrm{F}_{1-149}=1,244 ; \mathrm{p}>, 05\right)$ ve bilginin gerekçelendirilmesi $\left(\mathrm{F}_{1-149}=, 646 ; \mathrm{p}>, 05\right)$ boyutları arasında anlamlı farklılık olmadığı görülmüştür.

Fizik, kimya ve biyoloji öğretmenlerinin bilimsel epistemolojik inançları üzerinde branşlarının etkisini belirlemek için tek faktörlü MANOVA yapılmıştır. Analiz sonuçları Tablo 8'de sunulmuştur.

Tablo 8. Fizik, kimya ve biyoloji öğretmenlerinin BEİ̈ boyutları ile branşlarına ilişkin tek faktörlü MANOVA

\begin{tabular}{|c|c|c|c|c|c|c|c|c|c|c|}
\hline \multirow{2}{*}{ Alt boyut } & \multicolumn{2}{|c|}{ Fizik } & \multicolumn{2}{|c|}{ Kimya } & \multicolumn{2}{|c|}{ Biyoloji } & \multirow{2}{*}{$F(2,148)$} & \multirow{2}{*}{$\mathbf{p}$} & \multirow{2}{*}{ fark } & \multirow{2}{*}{$\eta 2$} \\
\hline & & SS & & SS & & SS & & & & \\
\hline Bilginin kaynağ 1 & 3,700 & ,102 & 3,698 & , 101 & 4,040 & ,102 & 3,725 & ,026* & $\mathrm{B}>\mathrm{K}$ & ,048 \\
\hline Bilginin kesinliği & 3,524 &, 087 & 3,863 & ,086 & 4,092 &, 087 & 10,706 &, $000 *$ & $\begin{array}{l}\mathrm{K}>\mathrm{F} \\
\mathrm{B}>\mathrm{F}\end{array}$ & ,126 \\
\hline Bilginin gelişimi & 3,816 &, 081 & 3,990 &, 080 & 4,239 &, 081 & 6,895 &, $001 *$ & $\mathrm{~B}>\mathrm{F}$ &, 085 \\
\hline Bilginin gerekçelendirilmesi & 4,071 &, 094 & 4,103 & ,093 & 4,418 &, 094 & 4,154 &, $018 *$ & $\begin{array}{l}\mathrm{B}>\mathrm{F} \\
\mathrm{B}>\mathrm{K}\end{array}$ &, 053 \\
\hline
\end{tabular}


MANOVA sayıltıları kontrol edildiğinde Box M istatistiğine göre yayılma matrisinin homojenlik sayıltısı sağlandığ1 tespit edilmiştir $\left(\mathrm{F}_{20-78570.704}=1,034 ; \mathrm{p}=, 61\right)$. Wilks Lambda Testi sonuçları branşları açısından öğretmenlerin BEIÖÖ alt boyutlarının doğrusal kombinasyonlarının anlamlı bir farklılık gösterdiğini ortaya koymuştur (Wilk's $\left.\Lambda=, 805 ; \mathrm{F}_{2-148}=4,140 ; \mathrm{p}=, 00\right)$. Tablo 8'de öğretmenlerin branşları ile bilginin kaynağ $\left(\mathrm{F}_{2-148}=3,725 ; \mathrm{p}<, 05\right)$, bilginin kesinliği $\left(\mathrm{F}_{2-148}=10,706 ; \mathrm{p}<, 05\right)$, bilginin gelişimi $\left(\mathrm{F}_{2-148}=6,895 ; \mathrm{p}<, 05\right)$ ve bilginin gerekçelendirilmesi $\left(\mathrm{F}_{2-}\right.$ $\left.{ }_{148}=4,154 ; \mathrm{p}<, 05\right)$ boyutları arasında anlamlı farklılık bulunduğu belirlenmiştir.

Farklılığın kaynağını ortaya koymak amacıyla yapılan Tukey testi sonucunda bilginin kaynağı boyutunda biyoloji ( $\overline{\mathrm{x}}=4,040 \pm, 102)$ ve kimya öğretmenleri ( $\overline{\mathrm{x}}=3,698 \pm, 101)$ arasında biyoloji öğretmenlerinin lehine anlaml fark bulunmuştur. Bilginin kesinliği boyutunda kimya $(\overline{\mathrm{x}}=3,863 \pm, 102)$ ve fizik öğretmenleri $(\overline{\mathrm{x}}=3,524 \pm, 087)$ arasında kimya öğretmenleri lehine ve biyoloji ( $\bar{x}=4,092 \pm, 087)$ ve fizik öğretmenleri arasında biyoloji öğretmenleri lehine anlamlı fark oluştuğu görülmektedir. Bilginin gelişimi boyutunda biyoloji ( $\overline{\mathrm{x}}=4,239 \pm, 081)$ ve kimya öğretmenleri ( $\bar{x}=3,990 \pm, 080)$ arasında tespit edilen anlamlı fark, biyoloji öğretmenlerinin lehine görünmektedir. Bilginin gerekçelendirilmesi boyutunda ise biyoloji ( $\bar{x}=4,418 \pm, 094)$ ve fizik öğretmenleri ( $\bar{x}=4,071 \pm, 094)$ ile biyoloji ve kimya ( $\bar{x}=4,103 \pm, 093$ ) öğretmenleri arasında anlamlı fark bulunmuştur. Her iki durum için de biyoloji öğretmenleri daha yüksek ortalamaya sahiptir. Etki değerine bakıldığında, öğretmenlerin bilimsel epistemolojik inançları üzerinde branş değişkeni açısından belirlenen farkın bilginin kaynağı ve gerekçelendirilmesi boyutları için küçük, bilginin kesinliği ve bilginin gelişimi boyutları için orta düzeyde olduğu söylenebilir. Buna göre branş değişkeni bilginin kaynağı boyutu için \%4,8'lik, bilginin gerekçelendirilmesi boyutu için \%5,3'lük, bilginin kesinliği boyutu için \%12'lik ve bilginin gelişimi boyutu için \%8'lik bir etki büyüklüğüne sahiptir.

\section{Fizik, Kimya ve Biyoloji Öğretmenlerinin Felsefi Tercihleri ve Epistemolojik İnançları Arasındaki İlişkiye Yönelik Bulgular}

Fizik, kimya ve biyoloji öğretmenlerinin felsefi tercihleri ve epistemolojik inançları arasındaki ilişkiyi belirlemek amacıyla Pearson Korelasyon Katsayısı hesaplanmış, sonuçlar Tablo 9'da sunulmuştur.

Tablo 9. Fizik, kimya ve biyoloji öğretmenlerinin felsefi tercihleri ve epistemolojik inançları arasındaki ilişki

\begin{tabular}{|c|c|c|c|c|c|c|}
\hline & & Daimicilik & İdealizm & Realizm & Deneyselcilik & Varoluşçuluk \\
\hline \multirow{3}{*}{ Bilginin kaynağı } & $\mathrm{r}$ & ,097 &,- 019 & ,031 &, 075 &,- 135 \\
\hline & $\mathrm{p}$ &, 234 &, 813 &, 702 &, 357 & ,097 \\
\hline & $\mathrm{n}$ & 151 & 151 & 151 & 151 & 151 \\
\hline \multirow{3}{*}{ Bilginin kesinliği } & $\mathrm{r}$ &, 085 &,- 063 &, 017 &, 111 &,- 066 \\
\hline & $\mathrm{p}$ & ,297 &, 445 &, 835 &, 176 & ,419 \\
\hline & $\mathrm{n}$ & 151 & 151 & 151 & 151 & 151 \\
\hline \multirow{3}{*}{ Bilginin gelişimi } & $\mathrm{r}$ &, $197^{*}$ &, 100 & $210^{* k *}$ &, $162^{*}$ &, 110 \\
\hline & $\mathrm{p}$ &, 016 &, 224 &, 010 & ,048 &, 181 \\
\hline & $\mathrm{n}$ & 151 & 151 & 151 & 151 & 151 \\
\hline \multirow{3}{*}{ Bilginin gerekçelendirilmesi } & $\mathrm{r}$ &, 159 &, 117 &, $164^{*}$ & $213^{* * *}$ &,- 006 \\
\hline & $\mathrm{p}$ &, 051 &, 152 &, 044 & ,009 & ,941 \\
\hline & $\mathrm{n}$ & 151 & 151 & 151 & 151 & 151 \\
\hline
\end{tabular}

$* * \mathrm{p}<0.01, * \mathrm{p}<0.05$

Tablo 9'da görüldüğg̈ üzere BEİÖ’nün bilginin kaynağı boyutu ve bilginin kesinliği boyutu ile FTDF alt boyutları arasında bir ilişki bulunmamıştır. Bilginin gelişimi boyutu ile daimicilik $(\mathrm{r}=, 197 ; \mathrm{p}<, 05)$, realizm $(\mathrm{r}=, 210$; $\mathrm{p}<, 01)$ ve deneyselcilik $(\mathrm{r}=, 162 ; \mathrm{p}<, 05)$ arasında düşük düzeyde, pozitif yönde ve anlamlı bir ilişki vardır. Bilginin gerekçelendirilmesi boyutu ile realizm $(\mathrm{r}=, 164 ; \mathrm{p}<, 05)$ ve deneyselcilik $(\mathrm{r}=, 213, \mathrm{p}<, 01)$ arasında düşük düzeyde, pozitif yönde ve anlamlı bir ilişki bulunmuştur.

\section{Sonuç ve Tartışma}

Bu çalışmada Fizik, kimya ve biyoloji öğretmenlerinin tercih ettikleri eğitim felsefeleri ile bilimsel epistemolojik inançlarının belirlenmesi ve bu unsurlar arasındaki ilişkinin incelenmesi amaçlanmıştır. Analizlerle öncelikle öğretmenlerin felsefi tercihleri ve bilimsel epistemolojik inançlarının düzeyleri belirlenmiştir. Öğretmenlerin en yüksek katılım gösterdikleri FTDF alt boyutlarının sırasıyla; deneyselcilik, realizm, daimicilik, idealizm ve 
varoluş̧̧uluk olduğu görülmüştür. Çalışmada öğretmenlerin ilk tercihlerinin "deneyselcilik" üzerinde yoğunlaşması alanyazınla uyum göstermektedir. Özellikle öğretmen adaylarıyla yapılan çalışmalar, felsefi akımlar arasında ilk sırada deneyselciliğin -diğer adıyla ilerlemeciliğin- geldiğini göstermektedir (Doğanay, 2011; Duman, 2008; Geçici \& Yapıc1, 2008; Hayırsever \& Oğuz, 2017; Kozikoğlu \& Erden, 2018, Livingston, McClain, \& DeSpain 1995; Yokuş, 2016). Öğretmenlerin deneyselcilik akımına eğilim göstermesinin, yeni fen bilimleri öğretim programlarında yaparak yaşayarak öğrenmeye ağırlık verilmiş olmasından kaynaklanabileceği akla gelmektedir. Bu durum Doğanay (2011) tarafından, Cumhuriyet döneminden itibaren eğitim programlarında bu akımın temel anlayış olarak kabul edilmesinden kaynaklandığı şeklinde yorumlanmıştır.

Fizik, kimya ve biyoloji öğretmenleri arasında son sırada tercih edilen eğitim felsefesi ise "varoluşçuluk" olmuştur. Alanyazında, tersi bir sonuç olarak, ilk sırada varoluş̧̧uluğun geldiği araştırmalarda yer verilen çalışma gruplarının ilköğretime yönelik sözel bölüm öğretmen ve öğretmen adaylarından oluştuğu dikkati çekmektedir (AlkınŞahin, Tunca, \& Ulubey, 2013; Altınkurt, Yılmaz, \& Oğuz, 2012; Aslan, 2014; Çetin, İlhan, \& Arslan, 2012; Doğanay \& Sarı, 2003; İzalan, 2017; Kahramanoğlu \& Özbakış, 2018; Yılmaz \& Tosun, 2013). Bu durumun fen bilimleri ve sosyal bilimlerin doğasının farklı oluşundan kaynaklanabileceği düşünülmektedir. Bununla birlikte realizm, daimicilik, idealizm gibi daha geleneksel kabul edilen felsefeler orta sırada yer alırken, deneyselcilik ve varoluşçuluk gibi daha çağdaş felsefelerin hem ilk hem son sırada tercih ediliyor oluşu çalışmanın şaşırtıcı bir sonucu olmuştur. Buradan fizik, kimya ve biyoloji öğretmenlerinin yaparak, yaşayarak öğrenme ortamlarını destekledikleri; bununla birlikte öğrencilerin bireyselliklerini ortaya çıkarmayı amaçlamadıkları düşünülmektedir. Bu durum da fen bilimlerinin nesnel bir yapıya sahip olmasından kaynaklanabilir.

FTDF'de erkek öğretmenlerin benimsedikleri eğitim felsefesi "deneyselcilik" boyutunda kadınlara göre daha yüksektir. Ölçeğin diğer boyutlarında ise cinsiyete göre farklılık görülmemiştir. Deneyselcilik boyutunda erkeklerin daha yüksek puan almış olması Doğanay'ın (2011) çalışmasıyla benzerlik göstermektedir. Diğer çalışmalarda deneyselcilik boyutunda kadınların puanları erkeklere göre daha yüksektir (Beytekin \& Kadı, 2015; Doğanay \& Sarı, 2003; Duman \& Ulubey, 2008). Bununla birlikte Karadağ, Baloğlu ve Kaya'nın (2009) okul yöneticileriyle, Üstüner'in (2008) müfettişler ve sınıf öğretmenleriyle yürüttükleri çalışmalarda cinsiyet açısından felsefi anlayışların değişmediği görülmüştür.

Branş değişkenin etkisi incelendiğinde benimsenen eğitim felsefeleri ile branşlar arasında anlamlı farklılık olmadığı görülmüştür. Bu durum fizik, kimya ve biyolojinin benzer doğaları olmasından kaynaklanmış olabilir. Alanyazında branş değişkenine yönelik bir çalışmaya rastlanmamıştır. Bu nedenle bir genelleme yapılamamaktadır.

Bilimsel epistemolojik inançlar incelendiğinde öğretmenlerin BEİÖ’nün tüm alt boyutlarında gelişmiş inançlara sahip oldukları görülmektedir. Alanyazında sınıf öğretmenleri ile yapılan çalışmalarda öğretmenlerin sofistike inançlara sahip oldukları görülmüştür (Kahramanoğlu \& Özbakış, 2018; Karhan, 2007). Öğretmen adayları ile yapılan çalışmalarda da fen bilimleri alanında öğrenim görenlerin sosyal bilimler alanlarındakilere göre epistemolojik inançlarının daha gelişkin olduğu belirtilmiştir (Enman \& Lupart, 2000; Kürşad, 2015).

BEİÖ puanları üzerinde cinsiyetin etkisi incelendiğinde kadın ve erkek öğretmenler arasında istatistiksel açıdan anlamlı farklılık bulunmamıştır. Alanyazında bu konuda birbirinden farklı sonuçlar görülmektedir. Bu çalışmadaki sonuçlar cinsiyet değişkeninin epistemolojik inançlar üzerinde etkisinin olmadığını gösteren Aksan ve Sözer'in (2007), Chan'ın (2004), Izgar ve Dilmaç'ın (2008), Kaya ve Ekici'nin (2017), Öngen'in (2003), Terzi (2005) ve Tümkaya'nın (2012) bulgularıyla benzerlik göstermektedir.

BEİÖ puanları üzerinde branş değişkeninin etkisi araştırıldığında tüm boyutlar için anlamlı farklılık bulunduğu görülmüştür. Bilginin kaynă̆ı boyutunda biyoloji-kimya öğretmenleri arasında biyoloji öğretmenlerinin lehine anlamlı fark vardır. Bilginin kesinliği boyutunda kimya-fizik öğretmenleri arasında kimya öğretmenleri lehine ve biyoloji-fizik öğretmenleri arasında biyoloji öğretmenleri lehine anlamlı fark görülmüştür. Bilginin gelişimi boyutunda biyoloji-kimya öğretmenleri arasında tespit edilen anlamlı fark, biyoloji öğretmenlerinin lehine görünmektedir. Bilginin gerekçelendirilmesinde ise biyoloji-fizik öğretmenleri ile biyoloji-kimya öğretmenleri arasında anlamlı fark bulunmuştur. Her iki durum için biyoloji öğretmenleri daha yüksek ortalamaya sahiptir. Alanyazında branş değişkeninin araştırıldığı çalışmalarda kullanılan ölçekler, buradaki boyutlara sahip olmadığından sonuçlar arasında bir karşılaştırma yapılamamıştır. Ancak bu çalışmadan elde edilen bulgular, biyoloji öğretmenlerinin BEİÖ'nün tüm alt boyutlarında en yüksek puana sahip olduklarını göstermektedir. Bunun nedeninin, fizik ve kimyanın matematik ağırlıklı olmasına karşılık, biyolojinin daha kavramsal bir yapısının olmasından kaynaklandığını 
düşünülmektedir. Biyoloji öğretmenlerinin alanlarına yönelik kavramsal ve eleştirel bakış açıları bilgiye bakışlarında da etkili olmuş ve gelişmiş bilimsel epistemolojik inançlara sahip olmalarına katkıda bulunmuş olabilir.

Öğretmenlerin tercih ettikleri eğitim felsefeleri ile sahip oldukları bilimsel epistemolojik inançları arasındaki ilişki analiz yapılarak incelenmiştir. BEİÖ’nün bilginin kaynağı ve bilginin kesinliği boyutları ile öğretmenlerin felsefi tercihleri arasında bir ilişki bulunmamıştır. Aypay (2011), bireylerin bilginin kesin ve değişmez olduğuna olan inançları yükseldikçe geleneksel yaklaşımları daha fazla benimsediklerini ortaya koymuştur. Ancak bu çalışmada bu inançlara sahip olmanın geleneksel veya çağdaş yaklaşımları benimsemekle ilişkili olmadığı görülmüştür.

Bilginin gelişimi boyutu ile daimicilik, realizm ve deneyselcilik arasında düşük düzeyde, pozitif yönde anlamlı bir ilişki saptanmıştır. Bilginin gerekçelendirilmesi boyutu ile ise realizm ve deneyselcilik arasında düşük düzeyde, pozitif yönde anlamlı bir ilişki bulunmuştur. BEİÖ’nün bu boyutları ile hem geleneksel hem de çağdaş akımların pozitif ilişki içerinde olması çalışmanın beklenmeyen bir sonucu olmuştur. Epistemolojik inançlar ile birbirine zıt gibi görünen eğitim felsefeleri arasında pozitif ilişki bulunduğu gösteren sonuçlar alanyazında da görülmektedir (Biçer, Er, \& Özel, 2013; Önen, 2011). Öğretmenlerin sınıf içindeki uygulamalarının incelendiği çalışmalarda da öğrenmeye ve öğretmeye yönelik sahip oldukları inançlarla sınıftaki uygulamaları arasında tutarsızlık bulunduğu görülmüştür (Mansour, 2013; Sapkova, 2013; Tsai, 2007). Önen (2011) bu durumu çalışma grubunun geleneksel yaklaşımla öğrenim görmüş olmasına, çağdaş yaklaşımlara yakınlık duysalar bile yerleşmiş fikirleri ve içinde yetiştikleri anlayışı tamamen bırakamamış olmalarına bağlamıştır. Başka bir bakış açısı olarak ise, her bireyin farklı öğrenme stillerine sahip olduğu düşünüldüğünde, öğrenciyi ya da öğretmeni merkeze almasına bakılmaksızın, asıl önemli olanın öğretim ortamının öğrencinin özelliklerine uygun olarak tasarlanması olduğu düşünülebilir. Geleneksel anlayışla öğrenim görmüş olmalarına rağmen öğretmenlerin gelişmiş bilimsel epistemolojik inançlarının olması da bunu doğrulamaktadır. Ayrıca, ülkemizin başarı kriteri olan çoktan seçmeli sınav gerçeği, öğrencilerin eğitim ortamının zenginliğinden ziyade hızlı soru çözme yöntemlerini öğrenmeyi talep etmeleri, yetiştirilmesi gereken yoğun öğretim programı gibi unsurlar da düşünüldüğünde, öğretmenlerin sahip oldukları inançları eğitim ortamına yansıtmakta zorlanacakları da akla gelmektedir. Bu durumda öğretmenler epistemolojik inançlarından bağımsız olarak klasik eğitim anlayışını tercih etmek zorunda kalabilirler.

Alanyazında benimsenen eğitim felsefeleri ile bilimsel epistemolojik inançlar arasındaki ilişkiyi inceleyen sınırlı sayıda çalışma bulunmaktadır. Ayrıca bilimsel epistemolojik inançları ölçmek için kullanılan ölçeklerin birbirinden farklı boyutları ölçtügü görülmektedir. Bu nedenle çalışma bulguları arasında bu yönde bir karşılaştırma yapılamamaktadır. Genel bir sonuca ulaşmak için gelecekte farklı çalışma gruplarıyla yapılacak çalışmalara ihtiyaç duyulmaktadır. 


\section{Kaynaklar / References}

Akbulut, Y. (2011). Sosyal bilimlerde SPSS uygulamalart. İstanbul: İdeal.

Aksan, N. \& Sözer, M. A. (2007). Üniversite öğrencilerinin epistemolojik inançları ile problem çözme becerileri arasındaki ilişkiler. Ahi Evran Üniversitesi Kırşehir Ĕ̈itim Fakültesi Dergisi, 8(1), 31-50.

Alkın-Şahin, S., Tunca, N., \& Ulubey, Ö. (2013). The relationship between preservice teachers' educational beliefs and critical thinking tendencies. In European Conference on Curriculum Studies. Future Directions: Uncertainty and Possibility, Portugal, Braga, 18-19 October 2013. University of Minho.

Alkın-Şahin, S., Tunca, N., \& Ulubey, Ö. (2014). Öğretmen adaylarının eğitim inançları ile eleştirel düşünme eğilimleri arasındaki ilişki. Elementary Education Online, 13(4), 1473-1492.

Altınkurt, Y., Yılmaz, K., \& Oğuz, A. (2012). İlköğretim ve ortaöğretim okulu öğretmenlerinin eğitim inançları. On Dokuz Mayls Üniversitesi Ĕ̆itim Fakültesi Dergisi, 31(22), 1-19.

Angeli, C., \& Valanides, N. (2012). Epistemological beliefs and ill-structured problem-solving in solo and paired contexts. Journal of Educational Technology \& Society, 15(1), 2-14.

Apps, J.W. (1973). Toward a working philosophy of adult education. https://files.eric.ed.gov/fulltext/ED078229.pdf adresinden erişilmiştir.

Aslan, Ö. M. (2014). Eğitim felsefesi dersinin okul öncesi öğretmen adaylarının felsefi tercihlerine ve eleştirel pedagojiye yönelik görüşlerine olan etkisi. Elektronik Sosyal Bilimler Dergisi, 13(48), 1-14.

Austin, J.R. \& Reinhardt, D.C. (1999). Philosophy and advocacy: An examination of preservice music teachers' beliefs. Journal of Research in Music Education, 47(1), 18-30.

Ayaz, F. (2009). Fen bilgisi öğretmen adaylarının epistemolojik inançlarının yordanması (Yayımlanmamış Yüksek Lisans Tezi). Ege Üniversitesi Sosyal Bilimler Enstitüsü, İzmir.

Aybek, B., \& Aslan, S. (2017). Öğretmen adaylarının eleştirel düşünme eğilimleri ile benimsedikleri eğitim felsefelerinin çeşitli değişkenler açısından incelenmesi. Gaziantep University Journal of Social Sciences, 16(2), 373-385.

Aydın, H. \& Gür, H. (2017). A New Approach to change epistemological beliefs; discussion of the refutational texts. Necatibey Faculty of Education Electronic Journal of Science and Mathematics Education, 11(1), 160-173.

Aypay, A. (2011). Epistemolojik inançlar ölçeğinin Türkiye uyarlaması ve öğretmen adaylarının epistemolojik inançlarının incelenmesi [Adaptation of Epistemological Beliefs Questionnaire in Turkish and investigation of Pre-Service Teachers' Beliefs]. Eskişehir Osmangazi Üniversitesi Sosyal Bilimler Dergisi, 12(1), 1-15.

Bath, D. M. \& Smith, C. D. (2009). There lationship between epistemological beliefs and the propensity for life long learning. Studies in Continuing Education, 31(2), 173-189.

Baxter Magolda, M.B. (2004).Evolution of a constructivist conceptualization of epistemological reflection. Educational Psychologist, 39(1), 31-42.

Beytekin, O. F. \& Kadı, A. (2015). Öğretmen adaylarının eğitim inançları ve değerleri üzerine bir çalışma. The Journal of Academic Social Science Studies, 31, 327-341.

Beytekin, O. F., Kadı, A. \&Toprakçı, E. (2015). Öğretmen adaylarının kontrol odağı inançları ve eğitim felsefeleri. Yüksekögretim Dergisi, 5(1), 1-8.

Biçer, B., Er, H., \& Özel, A. (2013). Öğretmen adaylarının epistemolojik inançları ve benimsedikleri eğitim felsefeleri arasındaki ilişki. Journal of Theory \& Practice in Education (Jtpe), 9(3), 229-242.

Brown, D. F. \& Rose, T.J, (1995). Self-reported classroom impact of teachers' theories about learning and obstacles to implementation. Action in Teacher Education, 17(1), 20-29.

Büyüköztürk, Ş. (2012). Sosyal Bilimler Iç̧in Veri Analizi El Kitabı. Ankara Pegema Yayıncılık.

Campbell, L. P. (1990). Philosophy= Methodology= Motivation= Learning. The Clearing House, 64(1), 21-22. 
Can, A. (2014). SPSS ile bilimsel araştırma sürecinde nicel veri analizi (3. bask1). Ankara: PegemA.

Cevizci, A. (2015). Felsefe. Eskişehir: Anadolu Üniversitesi Yayınları.

Chan, K. W. (2004). Preservice teachers' epistemological beliefs and conceptions about teaching and learning: cultural implications for research in teacher education. Australian Journal of Teacher Education, 29(1), 1-14.

Chan, K. \& Elliott, R. G. (2002). Exploratorystudy of Hong Kong teacher education students' epistemological beliefs: Cultural perspectives and implications on beliefs research. Contemporary Educational Psychology, 27, 392-414.

Cheng, M. M. H., Chan, K. W., Tang, S. Y. F., \& Cheng, A. Y. N. (2009). Pre-service teacher education students' epistemological beliefs and their conceptions of teaching. Teaching and Teacher Education, 25(2), 319-327.

Cohen, L., Manion, L., \& Morrison, K. (2000). Research methods in education. London: Routledge Falmer.

Conley, A. M., Pintrich, P. R., Vekiri, I., \& Harrison, D. (2004). Changes in epistemological beliefs in elementary science students. Contemporary Educational Psychology, 29, 186-204.

Çalışkan, İ. (2013). Fen öğretmen adaylarının eğitim felsefesi yaklaşımları ile planlama süreçleri üzerine bir çalışma. Hacettepe Üniversitesi Ĕ̈itim Fakültesi Dergisi, Özel Sayl, 1, 683-772.

Çetin, B., İlhan, M., \& Arslan, S. (2012). Öğretmen adaylarının benimsedikleri eğitim felsefelerinin çeşitli değişkenler açısından incelenmesi. The Journal of Academic Social Science Studies, 5(5), 149-170.

Çoban, A. (2007). Sınıf öğretmenlerinin eğitim sürecine ilişkin felsefi tercihlerini değerlendirme. XIII. Ulusal Ĕgitim Bilimleri Kurultayı Bildiri Ö̈etleri Kitabı, 6-9 Temmuz 2004. Ankara: Pegem.

Demirel, Ö. (2002). Program development in education. Ankara: Pegem Yayınları.

Denessen, E. (2000). Opvattingen over onderwijs (Beliefs about education). Apeldoorn, The Netherlands: Garant.

Deryakulu, D. (2004). Epistemolojik inançlar. Yıldız Kuzgun \& Deniz Deryakulu (Ed.). Eğitimde Bireysel Farklılıklar içinde (ss. 259-288). Ankara: Nobel Yayınevi.

Deryakulu, D. \& Büyüköztürk, Ş. (2005). Epistemolojik inanç ölçeğinin faktör yapısının yeniden incelenmesi: Cinsiyet ve öğrenim görülen program türüne göre epistemolojik inançların karşılaştırılması. Eğitim Araştırmaları Dergisi, 18, 57-70.

Doğanay, A. (2011). Hizmet öncesi öğretmen eğitiminin öğretmen adaylarının felsefi bakış açılarına etkisi. Ĕgitim ve Bilim, 36(161), 332-348.

Doğanay, A. \& Sarı, M. (2003). İlköğretim öğretmenlerinin sahip oldukları eğitim felsefelerine ilişkin algılarının değerlendirilmesi. Türk Ĕ̈itim Bilimleri Dergisi, 1(3), 321-339.

Duell, O. K. \& Schommer-Aikins, M. (2001). Measures of people's beliefs about knowledge and learning. Educational psychology review, 13(4), 419-449.

Duman, B. (2008). Öğrencilerin benimsedikleri eğitim felsefeleriyle kullanıldıkları öğrenme strateji ve öğrenme stillerinin karşılaştırılması. Çukurova Üniversitesi Sosyal Bilimler Enstitüsü Dergisi, 17 (1), 203-224.

Duman, B. \& Ulubey, Ö. (2008). Öğretmen adaylarının benimsedikleri eğitim felsefelerinin öğretim teknolojilerini ve interneti kullanma düzeylerine etkisi ile ilgili görüşleri. Muğla Üniversitesi Sosyal Bilimler Enstitüsü Dergisi, 20, 95-114.

Ekiz, D. (2007). Öğretmen adaylarının eğitim felsefesi akımları hakkında görüşlerinin farklı programlar açısından incelenmesi. Ondokuzmayıs Üniversitesi Eğitim Fakültesi Dergisi, 24, 1-12.

Elisasser, C. W. (2008). Teaching educational philosophy: A response to the problem of first-year urban teacher transfer. Education \& Urban Society; 40 (4), 476-493.

Enman, M. \& Lupart, J. (2000). Talented female students'resistance to science: an exploratory study of post-secondary achievement motivation, persistence and epistemological characteristics, High Ability Studies, 11(2), 161-178.

Er, K. O. (2013). A study of the epistemological beliefs of teacher candidates in terms of various variables, Eurasian Journal of Educational Research, 50, 207-226. 
Ergün, M. (2011). Eğitim Felsefesi. Ankara: Pegem.

Eroğlu, S. E. \& Güven, K. (2006). Examination of epistemological beliefs of university students in terms of some variables, Selçuk University Journal of Institute of Social Sciences, 16, 295-312.

Fraenkel, J. R. \& Wallen, N. E. (2009). How to design and evaluate research in education (Seventh ed.). New York: McGrawHill.

Geçici, S., \& Yapıc1, Ş. (2008). İlköğretim öğretmenlerinin eğitim felsefesiyle ilgili görüşleri. Kuramsal Eğitimbilim Dergisi, l(2), 57-64.

Gunzenhauser, M. G. (2003). High-stake testing and the default philosophy of education. Theory into Practice, 42(1), 51-58.

Gutek, G. L. (2001). Eğitime felsefi ve ideolojik yaklaşımlar. (Çev. N. Kale). Ankara: Ütopya Yayıncılık.

Gutek, G. L. (2014). Eğitime felsefi ve ideolojik yaklaşımlar (Çev. N. Kale). Ankara: Ütopya Yayınları.

Gürol, A., Altunbas, S., \& Karaaslan, N. (2010). Öğretmen adaylarının öz yeterlik inançları ve epistemolojik inançları üzerine bir çalışma. e-Journal of New World Sciences Academy, Education Sciences, 5(3), 1395-1404.

Hayırsever, F. \& Oğuz, G. (2017). Öğretmen adaylarının eğitim inançlarının eleştirel düşünme eğilimlerine etkisi. Abant İzzet Baysal Üniversitesi Eğitim Fakültesi Dergisi, 17(2), 757-778.

Izgar, H., \& Dilmaç, B. (2008). Yönetici adayı öğretmenlerin özyeterlik algıları ve epistemolojik inançlarının incelenmesi. Selçuk Üniversitesi Sosyal Bilimler Enstitüsü Dergisi, 20, 437-446.

İzalan, Z. (2017). Sınıf öğretmenlerinin eğitim inançları ile eğitim programına iliş̧in metaforik algılarının karş̧laş̧tırlması (Yayımlanmamış Yüksek lisans tezi). Celal Bayar Üniversitesi, Sosyal Bilimler Enstitüsü, Manisa.

Kagan, D. M. (1992). Implications of research on teacher belief. Educational Psychologist, 27, 65-90.

Kahramanoğlu, R. \& Özbakış, G. (2018). Sınıf öğretmenlerinin eğitim inançlarının ve epistemolojik inançlarının belirlenmesi ve aralarındaki iliş̧kinin incelenmesi. Disiplinlerarası Ĕ̆itim Araştırmaları Dergisi, 2(3), 8-27.

Karabulut, E. O. \& Ulucan, H. (2012). Beden eğitimi öğretmenliği adaylarının bilimsel epistemolojik inançlarının farklı değiş̧kenler açısından incelenmesi. Spor ve Performans Araştırmaları Dergisi, 3(2), 39-44.

Karadağ, E., Baloğlu, N., \& Kaya, S. (2009). Okul yöneticilerinin eğitim felsefesi akımlarını benimseme düzeylerine ilişsin ampirik bir çalışma. Uludağ Üniversitesi Felsefe Dergisi, 12, 181-200.

Karakuş, M. (2006). Öğretmen Yetiştirmede Felsefenin Yeri ve Önemi. Çukurova Üniversitesi Eğitim Fakültesi Dergisi, 1(31), $79-85$.

Karasar, N. (2012). Bilimsel Araştırma Yöntemi. Ankara: Nobel Yayınevi.

Karhan, İ. (2007). İlköğretim okullarında görev yapan öğretmenlerin epistemolojik inançlarının demografik özelliklerine ve bilgi teknolojilerini kullanma durumlarına göre incelenmesi (Yayımlanmamış Doktora Tezi). Yıldız Teknik Üniversitesi Sosyal Bilimler Enstitüsü, İstanbul.

Kaya, E. \& Ekiçi, M. (2017). Sosyal bilgiler öğretmenlerinin epistemolojik inançları ve öğretim stillerinin çeşitli değişkenler açısından incelenmesi. İlköğretim Online, 16(2), 782-813.

Kaymak, E. (2010). Öğrencilerin Epistemolojik İnanç Düzeyleri ile Fiziğe Ait Kavramsal Değişimleri Arasındaki İlişkinin İncelenmesi (Yayınlanmış Yüksek Lisans Tezi). Marmara Üniversitesi, İstanbul.

Kılıç, İ. \& Ural A. (2004) Bilimsel Araştırma Süreci ve SPSS ile Veri Analizi SPSS 12.0 for Windows. Ankara: Detay Yayıncılık.

Kıncal, R. Y. (2006). Eğitim bilimine giriş. Ankara: Nobel Yayın Dağıtım.

Kozikoğlu, İ., \& Erden, R. Z. (2018). Öğretmen adaylarının eğitim felsefesi inançları ile eleştirel pedagojiye ilişkin görüşleri arasındaki ilişkinin incelenmesi. İlköğretim Online, 17(3), 1566-1582. 
Kumral, O. (2015). Öğretmen adaylarının eğitim felsefeleri: Pamukkale Üniversitesi Eğitim Fakültesi örneği. Hasan Âli Yücel Ĕ̈itim Fakültesi Dergisi, 12(2), 59-68.

Kürşad, M. Ş. (2015). Bilimsel araştırmaya yönelik tutum ve epistemolojik inanç arasındaki ilişkinin incelenmesi. Abant İzzet Baysal Üniversitesi Ĕ̆itim Fakültesi Dergisi, 15(2), 217-246.

Livingston, M. J., McClain, B. R., \& DeSpain, B. C. (1995). Assessing the consistency between teachers' philosophies and educational goals. Education, 116 (1), 124-129.

Mansour, N. (2013). Consistencies and inconsistencies between science teachers ${ }^{e e}$ beliefs and practices. International Journal of Science Education, 35(7), 1230-1275.

Meral, Y. D. (2014). Ortä̈ğretim matematik öğretmenlerinin ĕgitim felsefesi görüşleri ve öğretme- öğrenme anlayışlarının yapılandırmacı ögrenme ortamı düzenleme becerilerine etkisi (Yayımlanmamış yüksek lisans tezi). Kocaeli Üniversitesi, Sosyal Bilimler Enstitüsü, Kocaeli.

Ornstein, A. C., \& Hunkins, F. P. (2012). Curriculum: Foundations, principles, and issues, student value edition. New Jersey: Pearson.

Öngen, D. (2003). Epistemolojik inançlar ile problem çözme stratejileri arasındaki ilişkiler: Eğitim fakültesi öğrencileri üzerinde bir çalışma. Eğitim Araştırmaları, 13, 155-163.

Önen, A. S. (2011). The effect of candidate teachers' educational and epistemological beliefs on professional attitudes. Hacettepe Üniversitesi Eğitim Fakültesi Dergisi, 41(41), 293-301.

Özba, B. Ç. (2015). Sosyal bilgiler öğretmeni adayların felsefi bakış açılarının öğretmenlik eğitimi sürecinde incelenmesi. Türkiye Sosyal Araştırmalar Dergisi, 19(1), 117-138.

Özbaş, B. Ç. (2015). Sosyal bilgiler öğretmeni adaylarının felsefi bakış açılarının öğretmenlik eğitimi sürecinde incelenmesi. Türkiye Sosyal Araştırmalar Dergisi, 19(1), 117-138.

Özkan, Ş. (2008). Modeling elementary students' science achievement: the interrelationships among epistemological beliefs, learning approaches, and selfregulated learning strategies (Yayımlanmamış Doktora Tezi). Ortadoğu Teknik Üniversitesi, Ankara.

Özkan, Ş. \& Tekkaya, C. (2011). How do epistemological beliefs differ by gender and socio-economic status?. Hacettepe Üniversitesi Ĕ̆itim Fakültesi Dergisi, 41, 339-348.

Pallant, J. (2005). SPSS Survıval Manual: A Step by Step Guıde to Data Analysis Using SPSS for Windows. Australia: Australian Copyright.

Phan, H. P. (2008). Predicting change in epistemological beliefs, reflective thinking and learning styles: A longitudinal study. British Journal of Educational Psychology, 78, 75-93.

Phillips, F. (2001). A research note on accounting students' epistemological beliefs, study strategies, and unstructured problemsolving performance. Issues in Accounting Education, 16 (1), 21-39.

Sadıç, A., Çam, A., \& Topçu, M. S. (2012). İlköğretim öğrencilerinin epistemolojik inançlarının cinsiyet ve sınıf düzeyine göre incelenmesi. X. Ulusal Fen Bilimleri ve Matematik Eğitimi Kongresi Bildiri Özetleri Kitab1,27-30 Haziran 2012 (27-30). Erişim adresi: http://kongre.nigde.edu.tr/xufbmek/dosyalar/tam_metin/pdf/2266-18_05_2012-14_43_19.pdf

Sang, G., Valcke, M., Van Braak, J., \& Tondeur, J. (2009). Investigating teachers' educational beliefs in Chinese primary schools: socioeconomic and geographical perspectives. Asia-Pacific Journal of Teacher Education, 37(4), 363-377.

San Mateo, R. A., \& Tangco, M. G. (2003). Foundation of education II (historical, philosophical and legal foundation of education). Quezon City: Katha Publishing Co. Inc.

Sapancı, A. (2012). Öğretmen adaylarının epistemolojik inançları ile bilişüstü düzeylerinin akademik başarıyla ilişkisi [The relationship of student teachers' epistemological beliefs and metacognitive levels with their academic achievement]. Celal Bayar Üniversitesi, Sosyal Bilimler Dergisi, 10(1), 311-331.

Sapkova, A. (2013). Study on latvian mathematics teachers espoused beliefs about teaching and learning and reported practices, International Journal of Science and Mathematics Education, 11(3), 733-759. 
Schommer, M. (1990). Effects of beliefs about the nature of knowledge on comprehension. Journal of Educational Psychology, $82(3), 498-504$.

Schommer, M. (1993). Epistemological development and academic performance among secondary students, Journal of Educational Psychology, 85(3), 406-411.

Schommer, M. (1998). The influence of age and education on epistemological beliefs. British Journal of Educational Psychology, 68(4), 551-562.

Schommer-Aikins, M., Duell, O. K,. \& Hutter, R. (2005). Epistemological beliefs, mathematical problem-solving beliefs and academic performance of middle school students, The Elementary School Journal, 105(3), 289-303, doi:10.1086/428745.

Sönmez, V. (2011). Eğitim Felsefesi (10. bask1). Ankara: An1 Yayınc1lı.

Stipek, D. J., Givvin, K. B., Salmon, J. M. \& MacGyvers, V. L. (2001). Teacherse beliefs and practices related to mathematics instruction. Teaching and Teacher Education, 17(2), 213-226.

Terzi, A. R. (2005). Research on scientific epistemological beliefs of university students, Afyon Kocatepe University Journal of Social Sciences, 7(2), 298-311.

Tozlu, N. (2003). Ĕ̌itim felsefesi. İstanbul: Milli Eğitim Basımevi.

Tsai, C.C. (2007). teachers' scientific epistemological views: The coherence with instruction and students' views. Science Education, 91, 222-243.

Tümkaya, S. (2012). The investigation of the epistemological beliefs of university students according to gender, grade, fields of study, academic success and their learning styles, Educational Sciences: Theory \& Practice, 12(1), 75-95.

Trakulphadetkrai, N. V. (2012). Relationship between classroom authority and epistemological beliefs as espoused by primary school mathematics teachers from the very high and very low socio-economic regions in Thailand. Journal of International and Comparative Education, 1(2), 71-89.

Topdemir, H. G. (2008). Felsefe. Ankara, Pegem Akademi.

Tuncel, G. (2004). Öğretmenlerin kendi eğitim felsefelerini inşa etmeleri üzerine. Kazım Karabekir Eğitim Fakültesi Dergisi, 10, $223-242$.

Uğurlu, C. T. \& Çalmaşur, H. (2017). Öğretmenlerin ve öğretmen adaylarının eğitim inançlarına ilişkin görüşleri: Bir karma yöntem çalışması. Adıyaman Üniversitesi Sosyal Bilimler Dergisi, 9, 215-258.

Üstüner, M. (2008). The Comparison of the Educational Philosophies of Turkish Primary School Superintendents and Teachers. Eurasian Journal of Educational Research (EJER), 33, 177-192.

Wiles, J., \& Bondi, J. (1993). The essential middle school. New York, NY: Macmillan.

Wiles, J. \& Bondi, J. (2007). Curriculum development: A guide to practice (Seventh Ed.). New Jersey: Pearson Merill Prentice Hall Inc.

Yapıc1, Ş. (2013). Öğretmen ve öğretmen adaylarının eğitim felsefeleri. Turkish Studies International Periodical for the Languages, Literature and History of Turkish or Turkic. 8(8), 1431- 1452.

Yeşilyurt, E. (2013). Scientific epistemological beliefs of primary school students. International Journal of Social Science, 6(1), 1587-1609.

Yılmaz, K., Altınkurt, Y., \& Çokluk, Ö. (2011). Eğitim İnançları Ölçeğinin geliştirilmesi: Geçerlik ve güvenirlik çalışması. Kuram ve Uygulamada Eğitim Bilimleri, 11 (1), 335-350.

Yılmaz, K. \& Tosun, M.F. (2013). Öğretmenlerin eğitim inançları ile öğretmen öğrenci ilişkilerine yönelik görüşleri arasındaki ilişki. Ĕgitim ve Öğretim Araştırmaları Dergisi, 2(4), 205-218.

Yokuş, T. (2016). Müzik öğretmeni adaylarının benimsedikleri eğitim felsefelerinin çeşitli değişkenler açısından incelenmesi. Muğla Sitkı Koçman Üniversitesi Ë̆itim Fakültesi Dergisi, 3(1), 26-36. 